GABRIELA ALMEIDA DE MOURA ESTEVÃO 

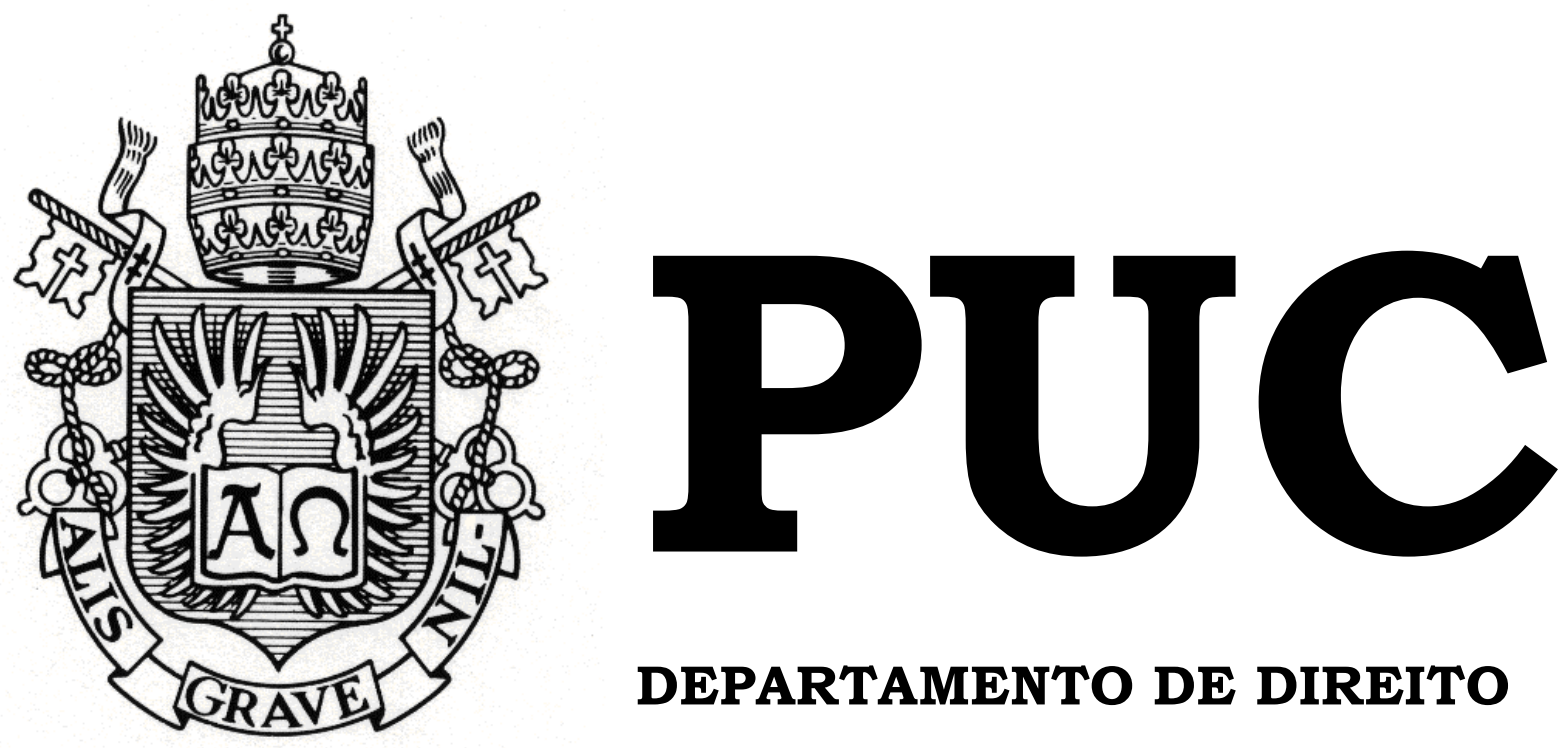

DEPARTAMENTO DE DIREITO

\title{
MEDO, EXCLUSÃO E CONTROLE SOCIAL
}

por

GABRIELA ALMEIDA DE MOURA ESTEVÃo

ORIENTADOR: JOÃO RICARDO WANDERLEY DORNELLES

2008.1

PONTIFÍCIA UNIVERSIDADE CATÓLICA DO RIO DE JANEIRO

RUA MARQUÊS DE SÃO VICENTE, 225 - CEP 22453-900

\author{
RIO DE JANEIRO - BRASIL
}




\title{
Medo, Exclusão e Controle Social
}

\author{
por \\ Gabriela Almeida de Moura Estevão
}

Monografia apresentada ao Departamento de Direito da Pontificia Universidade Católica do Rio de Janeiro (PUC-Rio) para a obtenção do Título de Bacharel em Direito.

Orientador:

João

Ricardo

Wanderley.

Dornelles 


\section{AGRADECIMENTOS}

Ao caríssimo prof. João Ricardo Wanderley Dornelles, por ter orientado minha monografia e todo meu processo de pesquisa, por ter intensificado e direcionado meu interesse pela criminologia, me apresentando diversos autores e teorias muito significantes para minha formação acadêmica e social, e pelo apoio e aconselhamento profissional nestes últimos dois anos de malabarismo cursando minhas duas faculdades .

Ao prof. Jorge Sapia pela grande ajuda que me prestou na elaboração do meu trabalho monográfico, revisando os meus escritos, indicando artigos e livros, e dando valiosas opiniões acerca dos temas discutidos.

A Alexandre Mendes pelas indicações bibliográficas, e frutíferas discussões que tivemos durante nossas reuniões de pesquisa, que muito me auxiliaram para melhor compreender as questões políticas e sociais da realidade contemporânea.

Aos professores Breno Melaragno, Elisabeth Sussekind e Rafael Medina, por terem aberto horizontes para mim no estudo das ciências penais e criminológicas, e ter sempre me estimulado a aprofundar meu conhecimento.

A minha querida Mãe pela pessoa maravilhosa que é. Pela dedicação, paciência, carinho, e cuidado que teve comigo desde meus primeiros suspiros. Por ter me ensinado a amar as artes e a vida. Por acreditar no meu potencial. E, é claro pela preciosa ajuda que me deu nestes últimos meses enquanto elaborava minha monografia.

Ao meu Pai, por tudo que me ensinou, pela preocupação, os conselhos e pelo amor que, mesmo estando longe, sempre me dá.

To Beth Anne for her love and understanding, and also for teaching me the important skills of outlining and scientific essay writing.

Aos meus irmãos Ian, Nate e a Rebecca pela alegria contagiante que provocam por todo lugar que passam, pelos sorrisos delicados e inocência que fazem da vida algo mais bonito.

Aos meus avós Alfredo e Lúcia, por serem como são, lindos, por todo amor que me dão, pelos cuidados, pelas histórias e pelo apoio sincero que dão a todos os meus projetos.

Ao meu avô Marcello, querido, pelo carinho, preocupação, e pelos conselhos .

To Lee Hagy, my best friend and great inspiration, who understands me better

most. 
A Carolina Godinho e Peter Boos, pelo acolhimento nos momentos difíceis e pelas aventuras teatrais que passamos juntos sempre com muito bom humor.

A Gabriel Delfino Marques, pela companhia, as risadas e o carinho.

A Guilherme Franqueira, e a João Paulo Porto, por nossas maravilhosas e hilariantes reuniões para assuntos jurídicos e aleatórios.

A João Paim Maciel, pelo apoio e por dividir comigo o gosto pelo cinema, pelo jazz e por uma boa poesia.

A Rubia Agatz, pela bonita amizade, o suporte e o acolhimento.

A Simone Franzen, grande amiga e companheira de gargalhadas, por me ensinar a ver a vida de uma maneira leve e otimista.

A Thiago Valente, por todo apoio, paciência, e companheirismo durante a maior parte da minha trajetória como aluna na PUC. 
"As one reads history... one is absolutely sickened, not by the crimes that the wicked have committed, but by the punishments that the good have inflicted; and a community is infinitely more brutalized by the habitual employment of punishment than it is by the occasional occurrence of crime" 


\section{RESUMO}

Esta monografia tem o objetivo de estudar a questão do medo e da exclusão social na sociedade contemporânea através de um estudo bibliográfico de obras relevantes para o tema. Para tanto, primeiramente é feita uma contextualização, abordando a nova lógica de acumulação de capital do final do século XX, qual seja, o capitalismo de acumulação flexível. Em seguida, são analisados os impactos deste novo regime na realidade social, um deles sendo a flexibilização das relações de trabalho e o conseqüente desemprego estrutural de uma parcela da população, a qual se torna excluída do mercado de consumo. É discutida, então, a ameaça que os setores improdutivos, considerados o novo "inimigo interior" da sociedade contemporânea, representam aos ideais positivistas de "Lei e ordem" mantidos pelas classes dominantes, as quais passam a adotar mecanismos de controle social emergenciais e de caráter eficientista para conter as ditas "classes perigosas". Dando continuidade ao estudo, é feita uma explanação sobre o medo, suas causas e características contemporâneas, dentro de uma perspectiva sociológica e política. Por fim, é abordada a questão da construção do imaginário do medo, analisando o papel específico da mídia impressa. Estuda-se, também, o caso do Rio de Janeiro, traçando um histórico da pobreza na cidade, e versando sobre o discurso jornalístico carioca e o sentimento de insegurança na cidade.

Palavras- chave: Capitalismo, Estado Social, Estado de Proteção Pessoal, Exclusão social, Mecanismos de controle, Inimigo Interior, Medo, Mídia, Violência, Imaginário do medo, sentimento de Insegurança. 


\section{SUMÁRIO}

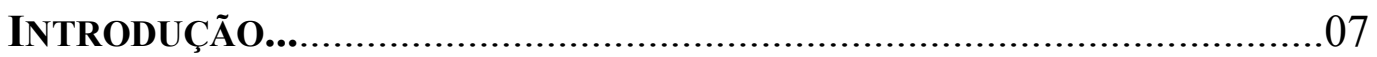

1- Contexto Histórico, ExClusão e Mecanismos de

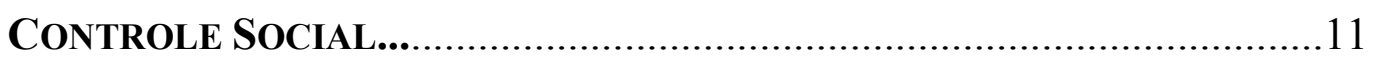

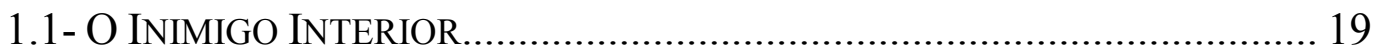

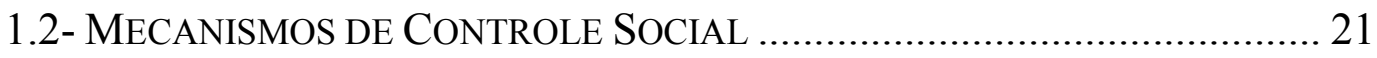

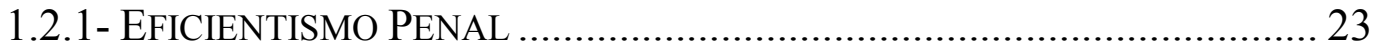

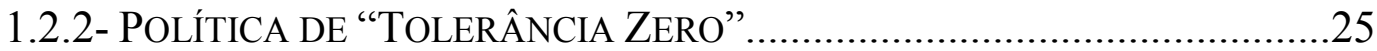

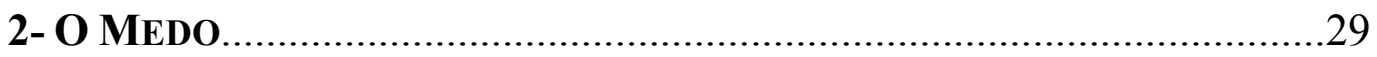

2.1-O MEDO ORIGINAL E SEUS DESDOBRAMENTOS......................................30

2.2- A PASSAGEM DO “ESTADO SOCIAL” PARA O “ESTADO DE

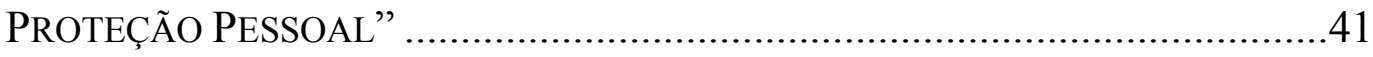

2.2.1- UM INIMIGO INTERNO: O TERRORISTA..............................................43

2.2.2- EXPLORAÇÃO ECONÔMICA DO MEDO.................................................4

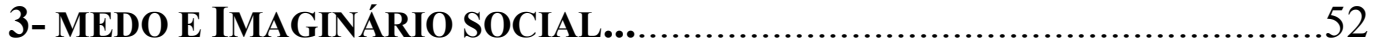

3.1- CONSTRUÇÃO DE UM IMAGINÁRIO SOCIAL DO MEDO.............................52

3.2- O MEDO NA CIDADE DO RIO DE JANEIRO, UMA PERSPECTIVA DE

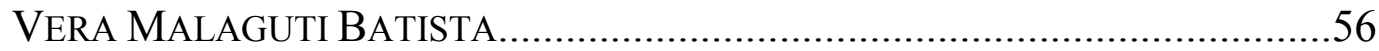

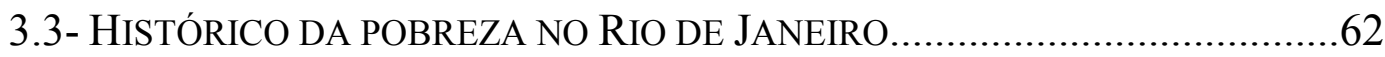

3.4-PESQUISAS SOBRE MÍDIA, CRIAÇÃO DE IMAGINÁRIO, E SENTIMENTO

DE INSEGURANÇA NO RIO DE JANEIRO .68

CONCLUSÃO

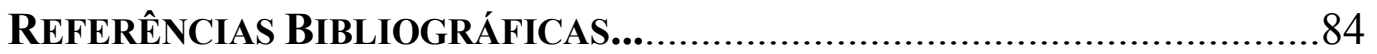




\section{Introdução}

A sociedade contemporânea é perturbada por um intenso sentimento de insegurança, instigado pelo constante bombardeamento de notícias e discursos que discorrem sobre a violência e as facetas da perversidade humana. Artigos da imprensa e discursos políticos versam constantemente sobre o problema dos roubos, dos homicídios com requinte de crueldade, da violência do tráfico, da ameaça terrorista.

Os cidadãos encontram-se cada vez mais oprimidos pelo modo de produção capitalista, que sofreu desde o século passado um processo de flexibilização de seus meios produtivos e de suas relações de trabalho, que gerou um alto número de desempregados e marginalizados, sem acesso ao mercado de consumo.

Tomados pelo medo da violência e do caos, as pessoas recorrem a formas particulares de segurança e muitos acabam apoiando políticas penais severas contra os supostos desviantes da sociedade.

Paralelamente a esse fato, há um crescente endurecimento das políticas penais dos países ocidentais em geral, com raras exceções, muitos com uma taxa crescente de encarceramento e uma política de aumento de penas e diminuição da maioridade penal.

O presente trabalho tem o objetivo de melhor compreender a natureza das políticas de controle social adotadas na atualidade, assim como sua relação com o grande número de excluídos do sistema capitalista, que acabam por se tornar a principal clientela do sistema penal. Outra finalidade dessa monografia, é compreender como o medo e a construção de um imaginário de insegurança são utilizados pelos grupos dominantes da sociedade contemporânea, e em que medida estes servem como 
mecanismos de legitimação de poder e dominação sobre os demais grupos sociais.

O método utilizado é o do estudo bibliográfico, no qual são analisadas diversas obras escritas por autoridades nos temas apontados.

Para traçar um panorama das mudanças sofridas pelo sistema capitalista no século passado, tomou-se como norte o livro de David Harvey, importante geógrafo e professor da universidade de Oxford, The Condition of Posmodernity, que apresenta uma análise dialética e profunda das transições econômicas, sociais e culturais no período de transição do que ele chama de condição moderna para uma condição pós-moderna.

Considerou-se relevante a obra de Zygmunt Bauman, sociólogo respeitado e conhecido estudioso da chamada conjuntura "pós-moderna". O livro sobre qual se fez uma análise mais aprofundada nesta pesquisa tem como tema central o medo, de nome Medo Líquido, o qual será um dos pilares da presente pesquisa.

Outro livro de grande relevância para o presente estudo é o Medo na Cidade do Rio De Janeiro, escrito por Vera Malaguti batista, que aborda a construção de um imaginário de medo em duas épocas da história carioca: o século XIX até o fim da escravatura, e o Rio de Janeiro a partir de 1992. Tal obra é uma fonte rica tanto sob perspectiva histórica como sociológica, haja vista que lança mão de diversos especialistas tanto da psicologia como da sociologia para abordar a questão do medo.

Para fins de análise dos mecanismos de controle social foi escolhida a obra de João Ricardo Wanderley Dornelles, Conflitos e Segurança, que faz um competente apanhado sobre os diversos mecanismos de controle empregados na sociedade pós-moderna. 
Os demais artigos e livros utilizados neste trabalho foram selecionados de maneira criteriosa por sua relação íntima com os assuntos a serem abordados.

O tema escolhido desta monografia é de grande relevância. O medo, a violência, as políticas de controle, e as medida de combate ao tráfico e ao terror são constantemente abordados nos jornais, em muitas publicações acadêmicas (algumas delas analisadas no trabalho), nas artes, e na cultura de massa (acabou-se de ver novelas e filmes retratando a realidade da favela, a violência policial, a insegurança e caos urbanos, como "Duas Caras", "Cidade de Deus", "Tropa de Elite", "Cidade dos Homens", “Ônibus 174”,e a criminalidade assim como temas relativos ao terrorismo, “United 93”, "Farenheint 9/11”, entre muitos outros.). Essa é uma discussão atual, que abrange $\mathrm{O}$ Estado, as grandes corporações, os cidadãos amedrontados, os excluídos e despossuídos. Todos esses grupos são envolvidos pelo imaginário do medo, seja na sua fabricação seja como seus alvos principais.

O presente trabalho monográfico não tem a pretensão de esgotar a questão do medo, do controle social, dos mecanismos de dominação e de exclusão, mas sim fazer uma análise cuidadosa destes elementos, e ver em que medida estes se inter-relacionam no contexto contemporâneo. Para tanto, o presente estudo se divide em três capítulos.

O primeiro capítulo consiste em uma breve análise sobre as transições ocorridas no modo de produção capitalista no século passado, as mazelas trazidas por este, principalmente a exclusão social de uma parcela da população, e um estudo dos mecanismos de controle social que passam a ser adotados, observando sua natureza eficientista . 
No segundo capítulo é discutida a questão do medo, e suas causas possíveis, sob uma perspectiva social e política. Serão tratadas as questões do medo da morte, do medo da exclusão social, da utilização econômica do medo, das possíveis manipulações do medo por parte do Estado e das grandes corporações serão tratadas.

Em seguida, no terceiro capítulo, é abordado o processo de construção do imaginário, discutindo-se o papel da estética e da mídia como formadores de representações do real. Por fim, é estudado o caso específico do Rio de Janeiro, analisando o seu histórico de pobreza e exclusão e também discutindo pesquisas de campo realizadas acerca da violência noticiada pelos jornais do Rio e o sentimento de insegurança experimentado pelos moradores da cidade carioca. 


\section{1- Contexto Histórico, Exclusão e Mecanismos de Controle Social}

Antes de falarmos de medo e exclusão é necessário compreender a grande mudança pela qual o sistema capitalista vem passando desde o início do século passado.

Mudança esta que se iniciou a partir da expansão do imperialismo dos Estados-nação europeus. Com a grande expansão das atividades industriais e o crescimento populacional experimentado na Europa do século XIX, os Estados-Nação passaram a ter uma maior necessidade de conquistar novos mercados consumidores para seus produtos industrializados, de encontrar novos fornecedores de matéria prima para produção, de realocar um contingente populacional excedente das nações européias, e de encontrar novas possibilidades para investimentos de capitais. Tais necessidades levaram a uma colonização e partilha de domínio sobre os continentes africano e asiático por parte de países industrializados da Europa. (VICENTINO, 1997, p. 332). Este processo levou a uma intensa competição entre os Estados dominadores, a qual demandava a aceleração do ritmo produtivo, estimulava a produção de um grande número de inovações tecnológicas e ocasionava um grande esforço de racionalização da produção.

F. W. Taylor, acadêmico que bem representava o esforço pela racionalização da produção, publica Os Princípios da Administração Cientifica em 1911, no qual sustenta que o aumento da produtividade do trabalho poderia ser obtido "através da decomposição de cada processo de trabalho em movimentos componentes e da organização de tarefas de trabalho fragmentadas segundo padrões rigorosos de tempo e estudo de movimento". (HARVEY, 1992, p. 121).

Tendo como grande influência as idéias contidas na obra de Taylor 
começou a se estruturar o regime fordista de produção. Segundo Harvey:

A data inicial simbólica do Fordismo deve por certo ser 1914, quando Henry Ford introduziu seu dia de oito horas e cinco dólares como recompensa para os trabalhadores da linha automática de montagem de carros que ele estabelecera no ano anterior em Dearbon, Michigan. Mas o modo de implantação geral do Fordismo foi muito mais complicado que isso. (HARVEY, 1992, p. 121).

Henry Ford instaurou o horário de trabalho de oito horas e cinco dólares por dia, com o intuito de disciplinar o trabalhador para participar do processo produtivo de linha de montagem, no qual exercia uma única atividade ao longo de sua jornada de trabalho que devia ser repetida exaustivamente. Para tanto, os trabalhadores eram minuciosamente treinados e controlados por uma "política de controle e gerência do trabalho", dentro de um contexto hierarquizado de produção. A disciplina e rotinização assim como a crescente designação de cargos administrativos de chefia criaram um ambiente de controle constante, de controle de trabalho sobre o trabalho que permitiram um aumento significativo de produtividade.

Para Harvey, O regime fordista tinha como grande diferencial:

“(...) seu reconhecimento explícito de que a produção de massa significava consumo de massa, um novo sistema de reprodução da força de trabalho, uma nova política de controle e gerência do trabalho, uma nova estética e uma nova psicologia, em suma, um novo tipo de sociedade democrática, racionalizada, modernista e populista.” (HARVEY, 1992, p. 121).

A forma hierarquizada de produção fordista, implicava na atribuição de uma atividade específica a ser exercida repetidas vezes para cada trabalhador. Tal lógica privava o operário do contato com o produto final, familiarizando-o apenas com uma pequena etapa de sua confecção. Assim, o regime alienava o trabalhador das demais etapas de confecção do produto, deixando este desprovido do poder intelectual sobre os meios de produção, e por isso distanciado do produto final. Desta forma a habilidade do operário foi perdendo a importância, transformando-o em apenas mais uma ferramenta necessária para o bom funcionamento da máquina produtiva. 
(HARVEY, 1992, p.122-123).

Para David Harvey, foi a partir da crise financeira de superacumulação de 1929 que o regime fordista passa a ser uma resposta fundamental aos problemas trazidos pela expansão capitalista. $\mathrm{O}$ esforço de reconstrução seguido da primeira guerra mundial assim como os altos níveis de desemprego oriundos da crise e a crescente "ameaça" comunista levaram as nações a verem o rigor e disciplina do Fordismo como uma grande solução.

O autor relata que a aceitação deste regime se deu gradualmente, sofrendo forte resistência na Europa, só sendo este plenamente implantado lá, depois da segunda guerra mundial com os esforços de reconstrução urbana das cidades européias no período pós segunda guerra mundial, orientados pelo plano Marshall, proposto em 1947 por George Marshall, secretário de Estado dos Estados Unidos do governo Truman, e assinado pelos países da Europa ocidental.

O modo de produção fordista só chegou à maturidade, no entanto, após 1945. Neste momento os Estados-nação conseguem, de maneira mais concreta, resolver e usar seus poderes para intervir e exercer controle sobre a economia visando o aumento de investimento global para dar novo fôlego às suas economias. Controle este que para o economista Britânico Lord Keynes deveria ser o papel característico do Estado, que tinha como objetivo manejar as crises cíclicas do capitalismo. Segundo Harvey, John Keynes foi um dos grandes defensores do intervencionismo estatal, e via como principal questão a necessidade de encontrar:

um conjunto de estratégias administrativas científicas e poderes estatais que estabilizassem o capitalismo, ao mesmo temo que se evitavam as evidentes repressões e irracionalidades, toda a beligerância e todo o nacionalismo estreito que as soluções nacional socialistas implicavam. É nesse contexto confuso que temos de chegar a arranjos políticos, institucionais e sociais que pudessem acomodar a crônica incapacidade do capitalismo de regulamentaras condições essenciais da própria produção. (HARVEY, 1992, p. 124). 
No contexto pós 1945, o Estado passou a exercer uma regulação macroeconômica, implementando políticas econômicas e fiscais através do investimento em infra-estrutura e do estímulo ao consumo e ao emprego. Formou-se, por sua vez, uma rede de políticas de bem-estar que viabilizou a sustentação de elevados níveis de consumo, proporcionou o pleno emprego e conseguiu trazer certa igualdade social. O Estado passou a se mostrar como reparador das "pequenas mazelas" resultantes da vigorosa expansão do capitalismo, mal este necessário para o bom andamento do "grande esquema das coisas”. Proporcionou-se, desse modo, suporte à população, conferindo-lhe direitos sociais e trabalhistas e fornecendo-lhes serviços de educação, saúde e habitação públicos. A partir de 1945 e até 1973 tem-se uma época de prosperidade do capitalismo, chamada por alguns de época de ouro, na qual os países europeus experimentaram um momento próspero na economia e na realidade social.(HARVEY, 1992, p. 134-135).

O bom funcionamento do regime fordista dependia do bom funcionamento dessa combinação "intervencionismo-fordismo". Para tanto, era preciso que as classes trabalhadoras fossem convencidas a aceitar a configuração fordista de trabalho, configuração esta que, como vimos, ocasionava a alienação do empregado. A aceitação só foi alcançada com o combate e derrota dos movimentos radicais operários que se manifestaram na época.

É importante lembrar também que a transformação nos métodos de trabalho trazida pelo Fordismo importou na prática de produção em larga escala e, por conseguinte, acarretou a necessidade de um grande mercado consumidor para absorver esse contingente produtivo. Tanto o governo como as corporações ocuparam-se então de estimular o consumo em massa.

Neste contexto do capitalismo fordista, David Harvey vê o 
surgimento de um novo homem, o qual é sujeito a condições de trabalho limitadoras e alienantes e é estimulado pelo ideal do consumo imoderado, consumo este que é visto como segredo para obtenção da felicidade.

Segundo David Harvey, no início da década de sessenta o modo de produção fordista passa a ter uma dificuldade de controlar as contradições inerentes do capitalismo cada vez mais aparente1. Essa quase incapacidade se deve basicamente à característica mais fundamental do regime: a rigidez. Tal traço podia ser detectado não só no âmbito de investimentos de capital fixo, como também na estrutura do de mercado de trabalho (sua alocação, seus contratos, sendo qualquer tentativa de flexibilização "embarreirada" pelo poder da classe operária), e nos compromissos estatais com as políticas de bem-estar social.

Como uma tentativa de contornar esse engessamento e desafogar a economia, muitos Estados escolheram flexibilizar a política de emissão de moedas, emitindo um grande número de notas. Tal medida trouxe uma alta avassaladora na taxa de inflação (HARVEY, 1990, p. 141-145).

Outro baque sofrido pelo regime foi devido à crise do petróleo de 1973 que teve como uma de suas mais graves conseqüências a crise no sistema fiscal dos "Wellfare State." Esta se deu devido a crescente demanda de práticas assistencialistas por parte da população vitimizada pela crise

1 Segundo Harvey, no período de 1963-75, a situação tanto do mercado norte-americano quanto do Europeu e Japonês era delicada. De acordo com o autor, as economias ocidentais além de sofrer um excesso de capacidade (um contingente excedente de equipamentos, plantas de produção, mão-de-obra) estavam submetidas a uma competitividade severa. Devido a isso, o mercado de propriedades e as instituições financeiras passaram a ter sérios problemas. A crise do petróleo em 1973 também agravou a situação desestruturando o mercado de energia e forçando às empresas a racionar o uso de combustíveis, re-planejar sua produção e controlar mais duramente a sua mão-de-obra. Além disso, o engajamento dos Estados unidos na luta contra a pobreza e na guerra do Vietnã e a posterior crise fiscal causada por uma significativa queda na produtividade e na lucratividade das corporações geraram a necessidade de emissão desenfreada de moeda e um conseqüente problema inflacionário. Também estavam em maus lençóis o mercado ocidental europeu e o japonês, já que precisavam urgentemente de políticas de exportação e inserção em mercados internacionais, e, por isso, tiveram que competir com o mercado norte- americano. Esse conjunto de fatores levou à quebra do acordo de Bretton Woods e a queda da importância do dólar. HARVEY, 1992, p. 143-45. 
econômica, e a incapacidade da receita de atendê-la. Essa incapacidade gerou insatisfação tanto nos contribuintes, que viam sua carga tributária cada vez mais aumentada, quanto nos que seriam beneficiados pela assistência, por não terem suas necessidades atendidas (HARVEY, 1990, p. 145). As corporações tentaram contornar os riscos subversivos desse descontentamento através da implantação de um regime ainda mais rígido de controle do trabalho, o que gerou ainda mais frustração nos trabalhadores.

Para combater a crise que se instaurava, uma série de medidas foi adotada, o que levou à formação de um regime de acumulação flexível, de flexibilização do mercado de trabalho e dos padrões de consumo. Os empregadores se aproveitaram do Estado enfraquecido dos sindicatos e do crescente número de desempregados desesperados para reformular o regimento do trabalho, priorizando a utilização "do trabalho em tempo parcial, temporário ou subcontratado" (HARVEY, 1992, p.143) 2 em detrimento do regime de emprego regular e estável. Cabe notar que essa mudança traz como grande desvantagem para o empregado a perda de benefícios e garantias trabalhistas, como bem explica Harvey:

esses arranjos de emprego flexíveis não criam por si mesmos uma insatisfação trabalhista forte, visto que a flexibilidade pode às vezes ser mutuamente benéfica. Mas os efeitos agregados, quando se consideram a cobertura de seguro, os direitos de pensão, os níveis salariais e a segurança no emprego, de modo algum parecem positivos do ponto de vista da população trabalhadora como um todo. (HARVEY,

2 Pode se delinear então uma nova estrutura de mercado de trabalho que é descrita da seguinte forma por Harvey: "O centro - grupo que diminui cada vez mais , segundo notícias de ambos os lados do atlântico- se compõe de empregados 'em tempo integral, condição permanente e posição essencial para o futuro de longo prazo da organização.' Gozando de maior segurança no emprego (...) esse grupo deve atender à expectativa de ser adaptável , flexível, e se necessário, geograficamente móvel. Os custos potenciais da dispensa temporária de empregados do grupo central em época de dificuldade podem, no entanto, levar a empresa a subcontratar mesmo para funções de alto nível (...), mantendo o grupo central de gerentes relativamente pequeno. A periferia abrange dois subgrupos bem distintos. O primeiro consiste em empregados em tempo integral com habilidades facilmente disponíveis no mercado de trabalho, como pessoal do setor financeiro, secretárias (...). Com menos acesso a oportunidades de carreira, esse grupo tende a se caracterizar por uma alta tava de rotatividade, 'o que torna as reduções da força de trabalho relativamente fáceis por desgaste natural'. O segundo grupo periférico 'oferece uma flexibilidade numérica ainda maior e inclui empregados em tempo parcial, empregados casuais, pessoal com contrato por tempo determinado, temporários, subcontratação e treinados com subsídio público, tendo ainda menos segurança de emprego que o primeiro grupo periférico.'(HARVEY, 1992, p. 144) 
1992, p. 143).

Como resultado das novas formas de organização do sistema capitalista de produção, multiplicam-se as políticas de demissão voluntária, de reestruturação e cortes nos quadros de pessoal de empresas, resultando em um enorme contingente de desempregados desprovidos da possibilidade de re-inserção no mercado, configurando uma situação de desemprego estrutural.

Segundo João Ricardo Dornelles, diante da nova realidade do mercado esses trabalhadores se viram tomados por uma nova subjetividade, a qual "apaga a memória e a consciência de classe, onde o trabalhador assalariado substitui a consciência coletiva pelo agradecimento por estar inserido no mercado.” (DORNELLES, 2003, p. 29).

O autor afirma que assim como a classe de trabalhadores, outros atores sociais de participação tradicionalmente ativa nos movimentos políticos de reivindicação de direitos também estavam desarticulados e desmobilizados. Essa crise de representação deu aos empregadores e grandes empresas considerável liberdade para implantar suas estratégias de produção e gestão da mão-de-obra.

Para agravar a situação dos desempregados, agora em altíssimo número, as políticas de bem estar social encontravam-se desestruturadas por essa nova estrutura do capitalismo, e estavam perdendo sua legitimidade. Um dos motivos desestruturadores foi a crescente onerosidade de tais políticas para os contribuintes e para o Estado. A questão do prejuízo material estava somada uma crescente expressividade do pensamento individualista, o qual se instaurava nas sociedades e trazia com ela a busca incessante dos cidadãos pela autopromoção. A partir desse pensamento individualista, surgiu o discurso que pregava a inexistência de razão moral para ajudar os setores improdutivos, e atribuía aos próprios excluídos a 
culpa pelas suas mazelas taxando-os de incapazes e preguiçosos. Recuperando o velho imaginário liberal do século XIX que via os setores populares como classes perigosas. Assim, mesmo aqueles que ainda poderiam recorrer às escassas medidas assistencialistas eram relutantes a fazê-lo, pelo fato de tal procura implicar na "confissão" deste Estado de incapacidade e derrota. (BAUMAN, 1998, Capts. II e III).

Cabe lembrar que estes excluídos estão inseridos numa cultura de consumo propagada desde a época fordista pelo Estado e pelas grandes corporações 3 e exacerbada no período pós-fordista. O consumismo, próprio deste último regime, tem como agravante a disseminação de uma idéia de descartabilidade dos produtos e de sua valia. Desta forma, os indivíduos agora se sentem compelidos não só a consumir muito, mas com grande freqüência, tendo o prazer, sentido pela aquisição de algo, uma duração curtíssima. (HARVEY, 1992, p. 146-150).

A impossibilidade de satisfazer tão forte ímpeto consumista leva a uma grande insatisfação destes desempregados e contribui para a verdadeira disseminação e fortalecimento de relações de trabalho informais, familiares, e até ilícitas, como o comércio de rua, e até o tráfico de entorpecentes e armas (BAUMAN, 1998, Capts. II e III). Estes trabalhadores produzem sem a proteção das garantias trabalhistas da formalidade, que por sua vez estão sofrendo processo de flexibilização.

A existência desse grupo que não possui as cartas do jogo de consumo, possui um caráter ambivalente. Se, por um lado apresenta uma

\footnotetext{
3 Harvey indica como reflexo da acumulação flexível, o expressivo aumento da concentração do poder corporativo: "num dos extremos da escala de negócios, a acumulação flexível levou a maciças fusões e diversificações corporativas. As companhias americanas gastaram 22 bilhões de dólares comprando uma às outras em 1977, mas, por volta de 1981, a cifra chegara a 82 bilhões, alcançando em 1985 um extraordinário pico de 180 bilhões". Também experimentou significativo crescimento o setor de serviços, que passou a atender a uma nova demanda de consumo e representou uma alternativa para expansão de mercados econômicos específicos. (HARVEY, 1992, p. 150).
} 
ameaça à ordem constituída devido ao expressivo número de insatisfeitos, ela também possui relevante utilidade. Isto porque esses "incapazes" são a personificação da tragédia e agrura que podem recair sobre o indivíduo que não participa do "jogo" de consumo ou que o fazem de maneira ilegal. Forma-se um poderoso mecanismo de controle que mantêm os "jogadores" calmos e inofensivos e inseridos no contexto produtivo. (BAUMAN, 1998, Capt. III).

Estes consumidores frustrados, situados à margem da sociedade assim, principalmente quando estes praticam atos ilícitos visíveis (como o tráfico de drogas, o terrorismo, o assalto à mão armada), representam, segundo Zygmunt Bauman, um inimigo interior da realidade do capitalismo pós-moderno.

\section{1- O Inimigo Interior}

Segundo Bauman em cada sociedade existe um movimento constante para a obtenção da ordem, sendo variáveis para cada grupo específico o método e os descontentes resultantes deste movimento. Quando uma ordem social vê sua identidade correndo algum risco, esta cria fantasias dos perigos que a cercam. Para lidar melhor com suas inseguranças e ansiedades, escolhe-se um inimigo para direcionar todo o medo e repulsa que acompanha a sociedade cotidianamente. Assim discorre Bauman sobre o inimigo interior:

De um modo geral (...) a imagem da ameaça tende a ser um auto-retrato da sociedade com um sinal negativo. A sociedade insegura da sobrevivência de sua ordem desenvolve a mentalidade de uma fortaleza sitiada. Mas os inimigos que the sitiaram os muros são seus próprios 'demônios interiores' - os medos reprimidos e circundantes que lhes permeiam a vida diária e a 'normalidade', e que, no entanto, a fim de se tornar suportável a realidade diária, devem ser dominados, extraídos do cotidiano vivido e moldados em um corpo estranho, um inimigo tangível com que se possa lutar. (BAUMAN, 1998. p. 52-53). 
Para ilustrar a coerência da escolha desse inimigo com a conjuntura e o espaço social em que está configurado o autor compara a escolha do inimigo interno moderno e o pós-moderno.

Os demônios interiores da modernidade eram os revolucionários, "as forças subversivas que tentavam substituir a ordem existente" (BAUMAN, 1998, P. 53). Nesse caso, o inimigo reencarnado na conspiração revolucionária refletia na verdade a tendência autodestrutiva do poder legislativo. Era uma época em que se buscava o avanço através de um esforço coletivo. Período no qual a tarefa de lidar com os riscos coletivamente produzidos era pública (o Estado era a fonte de ordem), no qual a indústria era a fonte de trabalho, e os que não estavam no sistema produtivo representavam um custo marginal da corrida do capital.

$\mathrm{Na}$ modernidade considerava-se um dever do Estado tornar disponível uma rede de bem estar para amparar o cidadão (para reabilitar os temporariamente inaptos e estimular os que estavam aptos a se empenharem mais, protegendo-os do medo) (BAUMAN, 1998, P. 54). Um bom exemplo dessa visão do Estado como garantidor de bem-estar é o período entre o fim da segunda guerra mundial e o choque do petróleo em 1973, o qual é conhecido como a época de ouro do capitalismo, como já foi mencionado.

Bauman aponta como inimigos internos na pós-modernidade aqueles que não participam do jogo de consumo, os desfavorecidos e os criminosos. Cabe relembrar que o Estado agora tem uma inserção nova no contexto econômico, exercendo não mais o papel de estimular o pleno emprego e ao consumo de massa, mas de regular o mercado financeiro, pagar as dívidas interna e externa,e a contenção da inflação. Este não mais oferece suporte às vítimas do sistema econômico. Houve uma privatização da tarefa de lidar com os riscos coletivamente produzidos. Estes excluídos são, portanto a corporificação dos demônios interiores da sociedade pós-moderna. 
Para os governantes, esse alto número de marginalizados, que Bauman chama de "refugo" (BAUMAN, 1998, P.57.), precisa ser contido e sua capacidade de resistência neutralizada, pois nada deve perturbar a ordem estabelecida, a qual é garantidora do bom andamento Da Sociedade de consumo e do sistema capitalista.

\section{2- Mecanismos de Controle Social}

João Ricardo Dornelles ao falar do conceito de controle social menciona as definições de Stanley Cohen e a de Juan S. Pergoraro.

Cohen apresenta o controle social como "um conjunto de meios pelos quais uma sociedade responde aos indivíduos ou grupos sociais que, de alguma maneira, colocam em risco a ordem estabelecida." (DORNELLES, 2003, p. 20). Ordem essa que, na conjuntura que se configurou a partir das duas últimas décadas do século $\mathrm{XX}$, tinha como pilar a lógica de produção do capitalismo de acumulação flexível. E, tinha como ameaça o grupo social que foi vítima do próprio sistema.

Já Pergoraro conceitua controle social como a estratégia tendente a naturalizar e normalizar uma determinada ordem social construída pelas forças sociais dominantes (DORNELLES, 2003, p. 22).

O processo de naturalização estaria intimamente ligado ao ideal positivista de "lei e ordem" mantido em alta conta pelo Estado e as classes dominantes desde o século XIX. Isto porque uma maneira de garantir a manutenção da ordem seria torná-la natural e aceita por todos os seguimentos da sociedade como a maneira normal do funcionamento da vida em conjunto. Se no processo de formação livre da ordem social um consenso coletivo consegue ser estabelecido, ou melhor, se a sociedade 
consegue ser convencida de que ele existiu, a ordem criada passa a ser dotada de legitimidade. Dentro desta noção de consenso social está encerrado um conjunto de bens jurídicos considerados relevantes pela coletividade e que, por isso, devem ser protegidos, e o são pelo direto penal. A partir do momento que a ordem é legitima assim também são, por extensão, os bens jurídicos e, conseqüentemente, o direito penal que os protege. (DORNELLES, 2003, Capt. II).

Da naturalização da ordem decorre a naturalização da desigualdade social e uma conseqüente conformidade, o que permitiu a diminuição considerável da aplicação por parte dos governos de medidas de desenvolvimento social, e a adoção de políticas assistencialistas. Tais políticas possuem um caráter neutralizador, pois não proporcionam um real melhoramento de condições de vida e trabalho para os setores sociais beneficiados, apenas servem como paliativo, apaziguador de insatisfações imediatas4.

As políticas de prevenção e proteção são direcionadas para um setor diferente da sociedade, os considerados "bons cidadãos" que participam do meio produtivo e do mercado de consumo.

A manutenção da ordem está ligada a noção de segurança. E para ilustrar tal relação é importante utilizar a noção de inimigo interno já exposta. O inimigo interno escolhido pelos grupos dominantes, apresenta perigo à ordem e por isso é "demonizado" e torna-se a personificação do mal e da ameaça. Os demais membros da sociedade são adestrados a temer estes inimigos como a fonte da insegurança que sentem. Os mecanismos produtores de discurso e ideologia, quais sejam as forças governantes, a

\footnotetext{
4 O parágrafo acima foi uma ilustração de como as políticas de controle social adotadas não visam melhorar a organização social mas sim manter e reproduzir a ordem estabelecida. $\mathrm{O}$ movimento de "lei e ordem" tem como objetivo a preservação da ordem através do combate aos inimigos e ameaças, não se preocupando, portanto, em fazer considerações valorativas acerca dos métodos e políticas de controle utilizados para tal. (DORNELLES, 2003, p.37)
} 
mídia e as grandes corporações, produzem um imaginário de insegurança, ao privilegiar a abordagem e discussão de práticas sociais ilícitas perpetradas pelo setor escolhido para ser "demonizado".

Essas práticas, por serem características de uma camada mais desfavorecida, ocorrem em locais públicos e ou de grande visibilidade (a rua, a praça, o ônibus). Essa visibilidade é registrada não só através de testemunhas oculares, mas também pelas câmeras, através de fotos e filmagens utilizadas em jornais impressos, telejornais, documentários e propagandas políticas, por exemplo. Dornelles aponta para o fato desse material concreto e visualmente expressivo ser um forte instrumento gerador de insegurança, inspirando nos cidadãos uma busca por segurança a qualquer preço.

A essa busca por segurança a qualquer preço alia-se intimamente a idéia de eficiência e de emergência. Quer-se reparar essa incerteza logo, da maneira mais rápida e eficaz, mesmo que isso signifique o sacrifício de garantias e direitos humanos. Passamos a ter uma política penal de emergência, um novo modelo que se baseia na insegurança social, tendo a figura do desviante (criminoso) a função de provocar temor e incerteza, de "construir um consenso social através do medo. (DORNELLES, 2003, p. 37.)

A essa busca pela eficiência através de políticas penais de emergência punitivas e da criminalização de conflitos sociais, movida pelos discursos de "lei e ordem", se dá o nome de eficientismo penal.

\subsection{1- Eficientismo Penal}

O eficientismo promove a repressão intensiva da população de rua, e das classes desfavorecidas em geral (não só os transgressores pontuais), e 
cultiva o estigma de "criminoso em potencial" que recai sobre todo esse grupo social. Há uma militarização da polícia, um pesado investimento no seu emparelhamento e uma belicização das terminologias usadas para tratar dos assuntos criminais. O número de mortes decorrentes de conflitos entre policiais e criminosos, os chamados autos de resistência a prisão, cresce expressivamente. Segundo Dornelles, há uma transição de uma política penal para uma política de segurança. Um endurecimento das penas, aumento da taxa de encarceramento, movimentos para a redução da maioridade penal. Desestimula-se a visão política de tensões sociais, adotando-se um tecnicismo que busca o combate a transgressões da ordem.(DORNELLES, 2003, p. 42).

Não se deve esquecer que na virada do século XX para o XXI passase a experimentar uma mistura de interesses do Estado e de interesses dos grupos econômicos. Há uma confusão entre o público e privado. Uma visão do Estado como mediador, como garantidor das condições propícias para o bom andamento do capitalismo de acumulação flexível. Observa-se um crescimento na demanda por segurança privada, além de propostas de privatização do sistema penitenciário.

Após maior análise dessa nova configuração das políticas penais, podemos ver que a forma considerada mais eficaz de conter a classe insatisfeita e excluída é neutralizá-la, despi-la de sua capacidade de resistência.

Para Bauman, a maneira encontrada foi a brutalização e criminalização desses grupos hipossuficientes. $\mathrm{O}$ autor argumenta que, para lidar com o contingente de excluídos (o inimigo interno da ordem vigente) os Estados substituem as políticas do bem-estar pelo controle social penal. (BAUMAN, 1998, Capt. III). 
Desde a década de oitenta percebeu-se no mundo, principalmente nos Estados Unidos, um endurecimento das legislações penais, as quais previram o aumento do quantum das penas de encarceramento, a aplicação mais ampla da pena capital, a diminuição da maioridade penal para o julgamento de determinados crimes. Com o controle social punitivo não se pretende mais recuperar ou re-inserir o excluído na sociedade e no mercado de trabalho, mas sim excluí-lo definitivamente e estigmatizá-lo, isolando-o no sistema prisional.

O clássico exemplo da adoção de políticas criminais eficientistas com esse fim de exclusão e neutralização do setor despossuído da sociedade e a política de "Tolerância Zero" adotada em Nova Iorque a partir de 1993 pelo prefeito da época Rudolf Giulliani. Tão emblemática é essa política que ela foi adotada em outros países, tanto da Europa como da América Latina em maior ou maior grau.

\subsection{2- Política de "Tolerância Zero"}

Desde a década de oitenta do século XX, Estados Unidos (nos governos de Reagan, George Bush, Clinton e o George Bush, o filho) adotou políticas penais crescentemente rigorosas. $\mathrm{O}$ encarceramento atingiu o número e 6.6 milhões (cerca de $3 \%$ da população) nas duas últimas décadas do século XX. Segundo Dornelles durante essa época os formadores de opinião neoconservadores (e.g. mídia, corporações, profissionais liberais, assim como parte da academia) encorajou a penalização da pobreza, criando a idéia de economia prisional, de indústria da segurança. (DORNELLES, 2003, p. 53- 56).

Devemos destacar que organizações como o Manhattan Institute e a Heritage Foundation (através de publicações e coisas parecidas) trouxeram para a mesa de discussões a "Broken Windows Theory", desenvolvida por 
James Wilson e George Kelling, que foi a base teórica para a aplicação da "Tolerância Zero", de Giuliani. A “teoria das janelas quebradas" defendia a persecução severa de pequenos delitos, contravenções e condutas desordeiras cotidianas como maneira de prevenir e retroceder os desvios, perturbações mentais que levam a práticas delituosas mais graves. (DORNELLES, 2003, P. 56 E 60).

Com a aprovação dessa teoria, os governantes nova-iorquinos passaram a reservar uma alta parcela do orçamento (em 1998 foi investido em segurança pública cerca de quatro vezes a quantia destinada à construção de hospitais) para o fortalecimento, emparelhamento das forças policiais, informatização do sistema, e os demais custos dessa política de persecução de pequenas infrações, as quais, eram praticadas principalmente pelas comunidades pobres das regiões guetificadas de Manhattan. $\mathrm{Na}$ verdade a população dessas áreas empobrecidas foi milimetricamente vigiada, monitorada e conseqüentemente repreendida por qualquer ato desordeiro, ou considerado como tal, que praticassem. Esse setor da população passou a ser tratado como de "transgressores em potencial". O delito praticado não era tão importante quanto aqueles que ainda poderiam vir a ser perpetrados e os locais os quais esses mais provavelmente iriam ser praticados. (DORNELLES, 2003, p. 53-63).

As autoridades governantes passaram a dar um tratamento penal para os problemas sociais, pois ao invés de investirem prioritariamente em políticas de educação saúde e geração de empregos, agora davam preferência a uma política de segurança que visava perseguir os "parasitas sociais", fonte de medo e insegurança, para proteger os "bons cidadãos". (DORNELLES, 2003, p. 61).

Um grande suporte teórico para os defensores da política de “tolerância zero" veio de Murray E. Herrnstein, um acadêmico da época, que levou mais longe a discussão sobre a pobreza, periculosidade e conflito, 
introduzindo um caráter biológico na sua análise, ao atribuir a desigualdade social nos Estados Unidos aos diferentes níveis de capacidade intelectual dos cidadãos. $\mathrm{O}$ autor alega que a inclinação para a prática tanto de crimes quanto de atos desordeiros tem direta relação com uma baixa capacidade cognitiva. Ele também dispõe que numa sociedade como a americana na qual é oferecida uma oportunidade igual a todos seus membros, o fracasso e a pobreza também estão diretamente ligados a um déficit de inteligência, basicamente responsabilizando os pobres por sua situação desfavorável. (DORNELLES, 2003, p. 57-59).

Ao dar uma justificativa biológica para as desigualdades, Herrnstein naturaliza o problema, torna essa configuração uma realidade normal que deve ser aceita tal como é. Para Dornelles, esta visão, por fim, legitima as políticas adotadas pelos governantes americanos em geral, Rudolf Giuliani em particular, que priorizam as medidas repressivas de segurança e o investimento no mercado financeiro e produtivo, deixando de lado as políticas assistencialistas, o investimento na educação, na saúde e na infraestrutura para as camadas baixas da população (a partir do momento que a pobreza e o desequilíbrio se tornam coisas naturais, as idéias de prevenção e recuperação perdem sua força mobilizadora).

A imagem do pobre como inadequado, perdedor, e preguiçoso foi amplamente difundida pelos veículos de comunicação de massa, desde os programas de TV até os filmes, e também pela educação dada às crianças nas escolas e pelos programas de treinamento nas grandes corporações. Concomitantemente, nestes mesmos meios, o homem bem sucedido era glorificado e considerado como um vencedor, um participante ativo do processo produtivo, do mercado financeiro e do mundo do consumo.

Outro fator que consagrou a "Zero Tolerance Policy" como modelo internacional de política de segurança, foi a súbita e radical mudança de 
abordagem por parte da mídia da cidade de Nova Iorque. Antes da aplicação da medida, Nova Iorque era vista como uma das cidades mais perigosas dos Estados Unidos e depois passou a ser, a partir de 1998, retratada como uma das mais seguras.

Acerca do assunto, Dornelles aponta para a declaração de Löic Wacqüant de que três anos antes da aplicação da nova estratégia de segurança instituições de pesquisa já tinham registrado uma queda na criminalidade não só em Nova Iorque, mas em Boston, Chicago e San Diego.

Essa repentina e injustificada mudança de tratamento dada pela mídia coroou a política de tolerância zero como o grande remédio para as mazelas, conflitos e insegurança das áreas urbanas.

Assim, temos estruturada e legitimada uma série de práticas que visam maximizar o controle, a vigilância, a punição e exclusão dos excluídos da sociedade, esse "outro" que é a materialização de todos os medos e inseguranças gerados pelo sistema capitalista neoliberal. A manipulação desse medo social se configura, pois, como um dos mais eficazes instrumentos de dominação encontrados na sociedade contemporânea. Dedicaremos nossos próximos capítulos a uma tentativa de maior compreensão desse fenômeno. 


\section{2-O Medo}

"It's not that I'm afraid to die, I just don't want to be there when it happens." Woody Allen

Diante de uma ameaça, os animais tendem a adotar duas possíveis reações: a fuga e a agressão. Tais respostas seriam impulsionadas por uma espécie de sentimento de medo primitivo. Medo este que é compartilhado entre grande parte dos seres vivos, e é muitas vezes chamado de instinto de sobrevivência. (BAUMAN, 2008, pg. 9).

Quando se trata de seres humanos, no entanto, uma espécie mais complexa de medo, a eles exclusiva, surge: um medo secundário que seria de natureza social. Este seria um elemento orientador dos comportamentos na sociedade sem que necessariamente existisse uma ameaça imediata ou presente à integridade ou bem-estar de alguém. Bauman define esse medo como "uma estrutura mental estável que pode ser mais bem descrita como o sentimento de ser suscetível ao perigo; uma sensação de insegurança (...) e vulnerabilidade (...)”. (BAUMAN, 2008, pg. 9).

Se fossemos incumbidos da tarefa de delimitar a causa primordial de temores em nós seres humanos ao longo da história, não tardaríamos em nomear a morte como vencedora e mais merecida dona de tal título. Como disse Zygmunt Bauman, esse é o "medo cósmico", "o horror primeiro dessa irremediável e inextirpável insegurança existencial que renasce todo dia com a lembrança inexorável de nossa vulnerabilidade última- a morte" (BAUMAN, 2000, p.67).

\footnotetext{
5 No presente capítulo o livro base utilizado para discutir o medo, seus papéis e configuração no contexto pós-moderno foi o "Medo líquido" de Zygmunt Bauman.
} 
Para se começar a entender a forma que o medo atua nos seres humanos e as diversas maneiras que este pode ser manipulada para fins dos mais variados é relevante a análise mais próxima desse teor existencial.

\section{1- O medo original e seus desdobramentos}

O medo da morte é dividido por Bauman em duas facetas: o medo original, o qual é compartilhado com os demais seres vivos e que se concretiza no instinto de sobrevivência, e o medo secundário, o qual só os humanos têm, que se constitui na consciência da inevitabilidade da morte (BAUMAN, 2008, p. 45-46).

Diversas culturas se ocuparam da missão de tornar mais fácil ou produtiva a convivência com essa certeza da morte. A maneira mais comum e adotada é a negação da morte como um fim definitivo. Surgiram crenças e religiões que pregaram continuidade da vida, em um plano distinto, imaterial e incorpóreo. A morte passou a ser vista por muitos como uma libertação, uma evolução, na qual a alma se desprende do corpo, que é revestido de limitações e impurezas.

Passou-se a se buscar também outras maneiras de driblar a morte. Uma muito utilizada é a imortalidade através da memória, que se desenha pela busca por uma individualidade, um rosto destacado da multidão sem face, pela fama e pelo reconhecimento de todos. O reconhecimento, a notoriedade é um caminho tortuoso que pode significar tanto a fama quanto a infâmia. A busca e manutenção da fama implica em constante vigilância, dedicação e persistência, assim como a salvação da alma na morte implicava em uma vida pura e sem pecado.

Aqueles que não atingem a glória individual, buscam muitas vezes o que Bauman chama de "imortalidade por procuração", que implica uma renúncia à individualidade. Esta imortalidade despersonalizada implica 
numa maneira de não passar a vida sem deixar algo de minimamente impactante para a história. Estes seres sem rosto atingem esta pequena porção de eternidade através da forma a qual morrem. Sim, a glória não atingida em vida pode, de certa forma ser alcançada através da morte por uma causa. Essa idéia foi vastamente explorada pelas classes governantes ao longo da história. Bauman cita como exemplo a república francesa pósrevolucionária e caracteriza essa "mortalidade compensatória" como uma estratégia que seria muito usada na modernidade, principalmente com a formação dos estados- nação. Estas nações, no início de sua constituição, necessitavam do patriotismo de sua população, um amor pela pátria nascente que disponibilizasse até a vida em sacrifício em prol da imortalidade da nação. Como bem disse Bauman 'a 'dignidade da morte' tinha o poder de re-significar até as vidas mais indignas" (BAUMAN, 2008, p. 54). Essa idéia do sacrifício pela “causa nacional” é usada até hoje pelos países, principalmente em época de guerra. (BAUMAN, 2008, p. 53-54).

Com o desenrolar da era moderna e a chegada da contemporaneidade (com sua fluidez nas relações humanas, fragmentação, o efêmero como qualidade dominante) outro mecanismo foi surgindo para complementar os demais já citados que estavam perdendo a força: o da marginalização das preocupações com a morte através da "desvalorização de tudo que seja durável, permanente, de longo prazo" (BAUMAN, 2008, P.56). Retirou-se o ponto de conexão entre uma vida mortal e o eterno. Com esse novo sistema procurou-se afastar da consciência humana a preocupação com a eternidade, com aquilo que ultrapasse a existência individual. Bauman diz que se alcança esse objetivo através da desconstrução da morte e da banalização desta.

Quanto à desconstrução Bauman cita Freud no que tange a tendência moderna de atribuir a morte a algum caso fortuito (doença, desgraça, idade avançada) reduzindo a morte "de necessidade à oportunidade." Com isso, 
há uma estipulação de uma causalidade específica ao acontecimento fatal. A visão da morte simplesmente como um resultado natural da vida não é utilizada nem vista como uma causa genuína. Essa idéia de uma possível evitabilidade da morte, ao atribuir-lhe uma causa determinada, seja um acidente, seja uma doença específica possui um fator desconstrutor da morte como força natural e inexorável. Bauman sintetiza esse mito da contingência da morte como: "construído e sustentado mediante a representação de um ato natural, como produto de muitas falhas humanas que poderiam ser evitadas ou tornadas evitáveis. (...) A naturalidade da morte é camuflada de cultura" (BAUMAN, 2008, p.58).

A desconstrução da morte, ao contrário do que se pode pensar, não levou ao esquecimento da certeza da morte, mas sim transformou uma preocupação futura acerca de um evento longínquo e certo em uma preocupação presente e constante, materializada em todos os possíveis objetos ou agentes concretos causadores da morte. A esta pluralidade ameaças constantes corresponde uma luta constante para combatê-las. A morte encontra-se pois "fragmentada em incontáveis preocupações com incontáveis ameaças, o medo da morte satura a totalidade da vida, embora na forma diluída de uma toxidade um tanto reduzida." (BAUMAN, 2008, p.59). Em outras palavras a preocupação com o fim deixa de se tornar insuportável mas passa a ser constante e concretizado em tarefas diárias de combate e prevenção.

A banalização da morte a que se refere Bauman consiste na realização de encenações freqüentes da morte ao longo da vida, tornando ordinário o enfrentamento constante que já foi mencionado.

Bauman aponta algumas formas de se experimentar a morte enquanto em vida. Uma delas, que não implica necessariamente em um sentimento de perda, é a morte de terceiros desconhecidos, a qual possui um 
caráter quase demográfico, isso porque, ao se reconhecer a mortalidade do ser humano, o fato de alguém em algum lugar distante eventualmente morra é esperado. Diametralmente oposta está a morte de alguém com o qual o sujeito já havia estabelecido uma proximidade, um rosto e não um número. Esta proporciona uma possibilidade de se experimentar de maneira mais próxima a terminalidade e irreversibilidade, podendo vir acompanhada de um intenso sentimento de perda, é o que o autor chama de "morte em segundo grau" (BAUMAN, 2008, p. 60-61).

$\mathrm{O}$ autor fala ainda de outra possibilidade, o que ele chama de morte em terceiro grau, que se refere a uma morte metafórica de alguém na nossa vida através do rompimento do relacionamento com elas, seja um fim de namoro ou de casamento (o que Bauman chama de simulacro da viuvez).

Ao relacionar essa morte simbólica com a qualidade flexível dos relacionamentos afetivos no contexto pós-moderno, Bauman aponta que através dessa "fissiparidade dos vínculos" que implica em rompimentos constantes, os indivíduos estariam passando por um "ensaio diário da morte". Passou-se a reconhecer a morte fundada na "fragilidade dos vínculos humanos" ao invés da morte "originada na fragilidade dos corpos" (BAUMAN, 2008, p. 64-65). Operou-se então uma banalização da morte através dessa constante repetição metafórica do fim materializada nos freqüentes desenlaces afetivos da atualidade.

Antes de prosseguir, é importante mencionar a breve relação que Bauman faz entre o medo e o riso para mostrar a transição da idéia de um medo cósmico para a de um medo fabricado ao longo da história. É importante ter-se em mente que por boa parte da história tal qual a conhecemos o "medo oficial" que pairava nas sociedades e era mediado pelos meandros rigorosos da lei, foi um medo cósmico, que estava permeado pelos mitos da criação, da revelação e da condenação eterna, e 
que era mediado pelos homens. O iluminismo teve o bravo papel de desconstruir esses mitos e conseqüentemente desmistificar boa parte desse medo oficial. (BAUMAN, 2000, p.66-67).

A partir do renascimento instaurou-se de maneira clara a oposição do riso e do medo tendo cada um ocasiões específicas para serem manifestados. O riso era basicamente reservado aos festejos de carnaval, e tinha um condão pessoal, "extra clerical e não governamental". Este tinha a função de libertar as pessoas do medo, de dar-lhes alívio e deixá-las próximas do mundo. Ele fazia face à austeridade tediosa da ordem e da oficialidade, representada por sua vez pelo medo. A Alternância entre essas duas esferas representava o que Bauman chamou de alternância entre "a conformidade à lei e a exuberância da comunhão humana." (BAUMAN, 2000, p.67-68).

A relação entre estes dois elementos podia ser vista nas guerras (com as trincheiras e os períodos de calmaria, ou as guerrilhas e as dispersões), na divisão do trabalho (que dá meios materiais para satisfazer as necessidades dos sujeitos que alternam entre o "tremor espiritual e a orgia"), e na sua complementaridade (na medida em medida que o riso fazia o medo ser suportável, o medo enquadrava o riso em certos limites). (BAUMAN, 2000, p. 68).

Com o advento da modernidade, essa fronteira entre riso e medo foi pulverizada e ambos se misturaram. O caráter complementar destes foi destruído, um não tinha mais o papel de conter o outro ou fazer o outro ser menos dilacerador. O riso passou a ser um grande aliado do poder, não mais significava rebeldia e sim uma submissão. (BAUMAN, 2000, p.68-69). 
Através dessa mescla, o medo ganhou um caráter privado, e passa a não ter mais um viés cósmico, sendo ele agora um medo fabricado pelos homens.

A diferença que Bauman aponta para os medos atuais é a questão do “desacoplamento entre as ações inspiradas pelo medo e os tremores existenciais que geraram os medos" ou seja, o" deslocamento dos medos" para áreas cotidianas com grande visibilidade que pouco têm em comum com as reais causas das ansiedades. (BAUMAN, 2008, p. 174).

Para entender o medo é importante entender a natureza dos perigos responsáveis pelo seu surgimento. Bauman apresenta três tipos de perigos : "os que ameaçam o corpo ou as propriedades"; "os que ameaçam a durabilidade ordem social e a confiabilidade nela"; e "os que ameaçam o lugar da pessoa no mundo (...) [ameaçam] a imunidade à degradação e à exclusão sociais". (BAUMAN, 2008, p. 10).

O surgimento desse medo teria uma relação maior com a falta de confiança dos humanos nas defesas que eles têm disponíveis do que nas ameaças que poderiam vir a se apresentar. Por isso, Bauman, tomando como base uma série de estudos, alega ser relativamente fácil desacoplar o medo secundário dos perigos que poderiam vir a ser a causa deste medo. Conseqüentemente, se poderia desviar as reações de agressividade e defesa resultantes, as quais, como já foi visto, seriam as reações típicas dos animais diante de uma possível situação de apuros, para um lugar outro que daquele correspondente aos perigos de fato responsáveis pela ameaça. (BAUMAN, 2008, p.10).

Ao falar das catástrofes naturais Bauman menciona Timothy Garton Ash e o temor da descivilização, que não deixa de ser uma espécie de "morte social". Este consiste no medo de que a sociedade ao se deparar com situações adversas e precárias (como a falta de saneamento, comida e condições mínimas de segurança) voltasse a um estado de caos e 
hostilidade, na qual cada um está por si e não existe um poder externo controlador e instaurador da ordem. Este medo da "desarticulação em grande escala" de tudo que é civilizado ganha uma expressão maior quando se destaca a qualidade abrangente da catástrofe natural, essa ataca indiferenciadamente, ou seja pode atingir desde o mais miserável até o mais prestigiado cidadão (BAUMAN, 2008, p.28).

O contraponto deste medo coletivo é o da exclusão singular do jogo de produção e consumo, ou seja da civilização, a idéia do sofrimento solitário e da convivência diária com os demais sujeitos, os quais ainda desfrutam das estruturas civilizadas disponíveis. Bauman chama isso do medo de uma catástrofe pessoal, a qual vem crescentemente ocorrendo no contexto pós- moderno.

A figura dos reality shows e sua política de eliminação exemplifica de maneira clara a construção de uma crença na inevitabilidade da exclusão e da conseqüente luta para evitar, a qualquer custo que esta aconteça. A eliminação praticada nestes programas é desvinculada à noção de merecimento, de justiça ou injustiça. Para os participantes, a eliminação é um destino inevitável, o acolhimento e a premiação uma dádiva rara. Os participantes do processo de expulsão, são já de início absolvidos por sua função de eliminadores. O autor observa que diferentemente do "Big Brother" de George Orwell, que foi desenvolvido como uma forma de manter as pessoas dentro de um regime rígido e controlado, o "Big Brother" reality show tem a função de botar seus integrantes para fora e assegurar que essa saída ocorra de maneira tranqüila e permanente. (BAUMAN, 2008, p.38-39).

Bauman compara os contos morais antigos, nos quais os bons eram elevados e recompensados e os maus punidos e estraçalhados, com os contos morais contemporâneos (concretizados nos realities-show), que 
trazem a punição como regra, e a recompensa uma exceção e nos quais o vínculo existente entre pecado e sanção e virtude e recompensa é agora tênue e fortuito. Nesta nova realidade "os vencedores são aqueles que escaparam à sentença universal da eliminação" (BAUMAN, 2008, p.43).

Os contos morais têm a função precípua de espalhar o medo. Bauman coloca que enquanto os contos morais antigos disseminam um medo redentor (ou seja, que vem acompanhado de uma forma de se desvencilhar deste, uma solução) os contos de nossa época possuem um caráter impiedoso, pois disseminam um medo insanável, são passíveis de esquecimento mas nunca de resolução. Bauman chama os contos morais atuais de "ensaios gerais da morte travestida de exclusão social" que nos "vacinam" contra o medo da morte, banalizando-o (BAUMAN, 2008, p.44).

O autor fala da crescente veiculação na mídia de advertências globais que alertavam a respeito do caráter letal de algum fenômeno natural que poderia estar por vir ou alguma substância química, ou coisa do gênero. Ele comenta a banalização destes ao longo do tempo, por conta da freqüência e multiplicidade de comunicados deste gênero.

A sociedade "liquido - moderna" seria uma maneira de tornar suportável o convívio com todos os medos fabricados da contemporaneidade, seria um instrumento para combater o pavor ao perigo e silenciar aqueles temores que ameaçam o bom funcionamento do sistema capitalista em voga. As sociedades realizavam o que Bauman, citando Thomas Mathiesen, chamou de "silenciamento silencioso". Tal procedimento seria estrutural (e, por isso não seria atribuído aos governantes), cotidiano (atingindo eficazmente todos os selecionados para serem expostos ao processo), "irrefreável” , e silencioso (facilitando sua 
legitimação e dinamismo emprestando ao método grande confiabilidade). (BAUMAN, 2008, p. 13).

Seguindo a lógica da liquidez da realidade contemporânea, os medos atuais passam por constante renovação e substituição. Estes, inseridos na lógica do mercado de consumo, impulsionam a compra de diversos produtos de cunho protetivo, e levam os consumidores a acreditar na eficácia destes para afastar os perigos que os cercam (BAUMAN, 2008, p.15). Bauman ilustra essa questão ao mencionar a constante divulgação e alarde de situações iminentes de extremo risco ${ }^{6}$ que propulsionam uma complexa rede de serviços e produtos com a suposta finalidade de prevenir ou auxiliar na recuperação dos possíveis danos decorrentes do episódio veiculado.

A luta contra os medos tem um caráter perpétuo e constante, na medida em que novos medos surgem e com eles novas demandas de consumo. A tendência contemporânea de lidar com os medos segue menos uma estratégia de extermínio dos perigos e mais de deslocamento destes. Isso é condizente com a realidade imediatista experimentada atualmente, na qual o futuro representa uma grande incógnita, algo diferente do que se experimenta no presente, tendo como um dos grandes nortes o retardamento do sofrimento e a busca pelo prazer imediato. Diante de uma incerteza acerca de eventos futuros, a saída menos angustiante é a fruição intensa do presente, do momento imediato que se está vivendo e que ainda não foi atingido pela fluidez imprevisível do contexto pós-moderno. Bauman exemplifica bem a problemática ao mencionar a substituição da poupança pelo cartão de crédito. Os consumidores não planejam ou se preocupam com o futuro, mas sim buscam o prazer imediato, custe o que custar, custo

\footnotetext{
6 Bauman ao falar deste tópico cita o exemplo do "bug" do milênio que movimentou a indústria da informática, com a produção de cursos e programas eletrônicos desenvolvidos especialmente para lidar com o possível problema que poderia trazer o referido vírus, medo esse que se instaurou quase concomitantemente com o lançamento das possíveis soluções para saná-lo (BAUMAN, 2008, p. 14).
} 
esse que no caso específico do consumo é sanado pelo crédito, que tem por característica intrínseca o adiantamento de algo que vai ser cobrado em momento futuro $^{7}$ (BAUMAN, 2008, p. 15-17).

O constante convívio com a incerteza leva a sociedade, segundo Bauman, a perseguir perigos visíveis, de fácil identificação e previsão. A ansiedade do perigo incalculável é substituída por um desvio de foco para problemas que podem ser resolvidos e um decorrente sentimento de controle (BAUMAN, 2008, p. 19-20). Desta maneira, deixa-se de pensar nas catástrofes, muitas vezes inevitáveis e imprevisíveis, nas questões de maior complexidade, preservando-se uma sanidade, e passa-se a ocupar-se com questões secundárias e palpáveis, de mais simples resolução. Estes problemas difíceis, no entanto, vêm à tona em intervalos, cada vez mais curtos, e com grande brutalidade, reavivando a memória de todos e desestabilizando esse sistema, desestabilização esta que permanece, no entanto, por um período limitado de tempo. ${ }^{8}$

Bauman fala que o tempo atual, nos países desenvolvidos do ocidente, seria talvez o mais objetivamente seguro já experimentado pela humanidade na história, ou seja, que estas pessoas pertencentes às sociedades desenvolvidas, como nos países Europeus e Norte- americanos, têm a sua disposição mecanismos diversos para combater as ameaças apresentadas pela natureza (das enfermidades às catástrofes naturais), pelas fraquezas e imperfeições de seus corpos, e pelos percalços advindos das agressões proferidas por outras pessoas (BAUMAN, 2008, p.168). No entanto, o autor descreve que neste mesmo tempo e nesses mesmos locais se experimenta um profundo sentimento de insegurança, um fascínio e

7 O autor sintetiza bem a questão na frase "Se as cadernetas de poupança implicam a certeza do futuro, um futuro incerto exige cartões de crédito." (BAUMAN, 2008, p.17)

8 A esse respeito, Bauman cita o exemplo do furacão Katrina que por um curto período de tempo interrompeu a lógica do prazer imediato e levou diversas figuras influentes e voluntários a se mobilizarem com a catástrofe e oferecer ajuda, a qual durou poucos meses. A tragédia pouco mobilizou o Congresso americano, que permaneceu adormecido diante dos fatos e pouco se movimentou para discutir a legislação de ajuda cabível. (BAUMAN, 2008, p. 23-25). 
obsessão por todos os supostos mecanismos garantidores de segurança, o qual é maior do que aquele experimentado por outras populações do passado e do presente. A esse respeito ele cita Robert Castel e diz:

Castel sugere que nosso sentimento agudo de insegurança deriva não tanto da carência de proteção quanto da inescapável 'falta de clareza de seu escopo' em um tipo de universo social que, como nosso, 'foi organizado em torno da infindável busca de proteção e da frenética busca de segurança' - estabelecendo assim padrões de proteção sempre crescentes, e previamente impensáveis, sempre à frente do que é atualmente possível de atingir. É nossa 'obsessão com segurança', assim como nossa intolerância a qualquer brecha- ainda que mínima- no seu fornecimento, que se torna a fonte mais prolífica, auto-renovável e provavelmente inexaurível de nossa ansiedade e nosso medo. (BAUMAN, 2008, p. 169).

Para Bauman, essa idéia de que se poderia atingir uma "segurança total" na qual todas as potenciais ameaças poderiam vir a ser neutralizadas, de que esse feito poderia ser alcançado, aliada a convicção de que esta ainda não foi atingida, traz uma recorrente ansiedade acompanhada de uma conseqüente frustração que "acrescenta ao dano da insegurança o insulto da impotência" com relação a seu estado de vulnerabilidade. Como decorrência disso, os grupos cujas esperanças foram traídas passam a procurar incessantemente pelos culpados por esse não adimplemento da segurança absoluta e busca ferozmente puni-los, com o objetivo de ter uma compensação por suas dores.(BAUMAN, 2008, p.170)'

Retomando as três fontes de insegurança citadas por Bauman, podese dizer que a humanidade, através do forte desenvolvimento tecnológico, fez progressos consideráveis na busca mecanismos eficazes de proteção contra as ameaças naturais e contra a fragilidade dos corpos. E que estas conquistas são reconhecidas como tais pelos acadêmicos e governantes, mesmo que questões sérias envolvendo tais assuntos sejam objetos de vasta discussão como as questões do desequilíbrio ambiental e a dos efeitos danosos que o progresso industrial trouxe ao planeta estão presentes, e das epidemias e doenças incuráveis. (BAUMAN, 2008, p. 170). 
Com relação à proteção contra agressão por parte de outro ser humano, no entanto, há um consenso de que esta não foi alcançada e que talvez tenha se tornado mais frágil do que em épocas anteriores. Para Bauman a insegurança moderna se caracteriza pelo "medo da maleficência humana e dos malfeitores humanos" que responsabiliza indivíduos determinados pelas mazelas sofridas pela coletividade (BAUMAN, 2008, p. 171).

Esta individualização da culpa tem direta conexão, por razões lógicas, ao crescente processo de individualização que a sociedade vem passando no contexto pós-moderno. Os indivíduos pós-modernos são freqüentemente estimulados a correr atrás de seus interesses, visando benefício e proteção próprios. Partindo do pressuposto de que todos têm como principal preocupação o seu bem-estar a despeito dos demais, a sociedade passou a viver em um ambiente de desconfiança, na qual se viu como ameaça o terceiro desejante e supostamente egoísta. (BAUMAN, 2008, p.172).

\section{2- "Globalização Negativa" e a passagem do "Estado Social" para o "Estado de proteção Pessoal"}

Antes de prosseguir a análise é importante abordar a combinação de duas questões: o crescente enfraquecimento do estado de bem estar (já citado no capítulo anterior) e o que Bauman chama de "ascensão contínua do populismo de mercado.” (BAUMAN, 2008, p. 175).

O Estado, ao passar a ocupar o lugar de regulador da economia e ceder crescentemente à força de outros poderes correspondentes ao mercado, passa a ter que cada vez mais se desdobrar para manter a ordem, ameaçada pelo expressivo número de excluídos e rejeitados do sistema. $\mathrm{O}$ Estado passa a ser submisso ao que Bauman chama de "globalização 
negativa" 9 , que é definida por ele como "a globalização altamente seletiva do comércio e do capital, da vigilância e da informação, da coerção e das armas, do crime e do terrorismo, todos os quais agora desdenham a soberania nacional e desrespeitam quaisquer fronteiras dos Estados" (BAUMAN, 2008, p. 126).

Tal globalização proporcionou a abertura forçada das sociedades, deixando-as vulneráveis, com toda a sua pluralidade, tomadas pelo medo da impossibilidade de defesa de suas fronteiras. A idéia de que todos estão em perigo paira nas cabeças dos indivíduos globais, os quais, segundo Bauman, só podem ocupar o lugar de "perpetradores, vítimas e baixas colaterais" (BAUMAN, 2008, p. 128).

Todos os prejuízos e danos que resultaram dessa versão perversa da globalização geraram sentimentos constantes de ressentimento e vingança. Tais sentimentos se direcionam ao outro desejante, que apresenta um obstáculo ao adimplemento dos desejos individuais do sujeito. É um mundo de perigos indefinidos e imprevisíveis, e não de riscos calculáveis e rotinizados. É nessa imprevisibilidade que reside a chave da vulnerabilidade sentida pela sociedade pós-moderna.

Esse desamparo não pode ser corrigido pelo Estado, que não mais é um Estado social.(BAUMAN, 2008, p. 126-131). Há a emergência do que Richard Rorty, citado por Bauman, chama de "superclasse global" que decide sobre as questões econômicas a despeito das legislações e, em última instância, das vontades dos eleitores. A ascensão dessa classe é apoiada pela ideologia do neoliberalismo que privilegia a classe rica, detentora de maior força, e vê o mercado como a melhor forma de se alcançar a democracia, apoiando a privatização dos serviços públicos em geral, o que possibilitaria

\footnotetext{
9 A este respeito Bauman dedica um capítulo inteiro de seu livro "Medo Líquido", além de discutir essa questão ao longo de suas obras, porém análise de tal conceito merece um trabalho a parte, por ser de grande complexidade.
} 
a livre escolha por parte dos indivíduos de acordo com seu melhor interesse.(BAUMAN, 2008, p. 191). O Estado perdeu sua função de controlador da economia, e por não mais poder oferecer à população a proteção adequada para enfrentar as situações de resistência e conflito, ele passa a recorrer a medidas emergenciais para manejar as situações de crise.(BAUMAN, 2008, p.192).

Nesta conjuntura, o Estado se vê desprovido de legitimação política, e passa a tentar reavê-la através do "combate aos perigos à segurança pessoal". Com isso o Estado, que antes era de bem estar e garantia o amparo do exército de reserva de mão de obra, dos cidadãos vitimizados pelo sistema fordista de produção, para um Estado de proteção social, na qual o foco era reprimir as ameaças corporificadas na figura dos criminosos e "vadios", os inimigos internos da sociedade contemporânea.(BAUMAN, 2008, p.193).

\subsection{1- Um inimigo interno: O Terrorista}

O terrorista é um dos exemplos que melhor clarificam a noção do uso da figura do inimigo interno para legitimar determinadas políticas do Estado, e por conseguinte a atuação do Estado em si. A figura do terrorista de fato existe e representa um perigo. A questão é que através de sucessivas manipulações, e da criação de um imaginário de medo, o terrorista passou a ser visto como uma ameaça muito mais perigosa do que é na realidade. A visão deturpada dessa modalidade de criminoso internacional legitimou o início de uma política de guerra por parte dos Estados, principalmente dos Estados Unidos. (BAUMAN, 2008, p. 195-196).

Essa guerra ao terrorismo alimentou a venda de armas de pequeno porte pelo mundo, as quais são responsáveis por grande número de mortes (cerca de meio milhão por ano), além de fomentar o mercado de artigos de 
segurança destinados a defesa pessoal e, acima de tudo, provocou o crescimento do medo nas populações mundiais (BAUMAN, 2008, p. 196). O medo exorbitante no imaginário social levou a aprovação de uma "legislação- antiterrorista" que tolhe flagrantemente as liberdades pessoais.

Uma tática rigorosa foi adotada pelas polícias: a de "atirar para matar”. Estratégia esta fadada a causar diversas fatalidades, como a que ocorreu em Londres, onde a polícia local atirou e matou o brasileiro Jean Charles de Menezes, o qual estava tranqüilamente utilizando o transporte do metro (BAUMAN, 2008, p. 197). Igual ou pior rigor e crueldade é encontrado nas prisões especiais de Guantánamo e Abu Ghraib, onde a tortura se tornou uma prática recorrente e basicamente permitida. $\mathrm{O}$ ímpeto da tortura, aliado aos avanços tecnológicos e um ambiente de forte pressão, resultam em um contexto de brutalização, não só dos detentos como também dos funcionários e agentes que trabalham nestas carceragens. ${ }^{10}$

Para Bauman, o Estado de proteção pessoal possui certas incompatibilidades com a democracia. Isso por que a democracia teria uma íntima ligação com "o capital de fé que o povo tem no futuro e na autoconfiança otimista em sua capacidade de agir" (BAUMAN, 2008, p. 200) e o Estado de proteção, por sua vez, se baseia precisamente no oposto, ou seja, no medo e na incerteza, os quais são fomentados constantemente através da produção e manutenção de um imaginário de terror.

Isto não quer dizer, no entanto, que essa nova figura estatal seja totalitária de fato, pois, na atualidade, há um processo crescente de esvaziamento e terceirização das funções antes exercidas por entes do Estado, movimento que é oposto aos ditames da lógica totalitária de governo ${ }^{11}$.

10 BAUMAN, Medo Líquido, pg. 197-198.

11 Segundo Bauman "num Estado totalitário em pleno funcionamento, as fronteiras entre o público e o privado se confundem e tendem a ser totalmente eliminadas, e as iniciativas do 
Pode se detectar, contudo, algumas inclinações totalitárias no Estado de proteção pessoal. No século $\mathrm{XX}$, os regimes totalitários alcançaram o domínio sobre as suas populações através de uma tática de medo, provocado pela forma imprevisível, extravagante e aleatória que praticava “a isenção da lei” (BAUMAN, 2008, p.202). Estes se apresentavam ao seu povo, no entanto como combatentes do terror e não como causadores deste terror. Tal imagem era reforçada através de esporádicos atos de perdão e benevolência, e da declarada proteção dos cidadãos obedientes e conscienciosos.

$\mathrm{Na}$ época do Estado Social, com a rede de amparo criada para lidar com os temporariamente excluídos do sistema produtivo, tínhamos como única desgraça o medo em si (BAUMAN, 2008, p. 204). ${ }^{12}$

Com a queda da rede de bem-estar, muitas inseguranças retornaram a superfície, de forma violenta, com um desemprego estrutural que levou ao que Bauman chama de passagem do "aburguesamento do proletariado" para" proletarização da burguesia". A idéia de plano de carreira e expectativas a longo prazo se tornou praticamente inviável. O Estado de proteção pessoal, portanto, para lidar com estas insatisfações e recuperar sua legitimidade emergente declarou guerra ao terrorismo, aos vadios e aos criminosos em geral. Desta forma, "O medo das ameaças à segurança pessoal (...) é que tende a ser indicado como esponja para macerar, absorver e varrer todos os outros medos." (BAUMAN, 2008, p.205-206).

Em um mundo globalizado, no qual há constante fomentação constante do medo, poder-se-ia dizer que os ricos, dotados de grande

Estado não são mais limitadas pelas inexpugnáveis liberdades individuais de seus cidadãos, consideradas sagradas." (BAUMAN, 2008, p.201)

12 É dessa época a frase de Franklin Delano Roosevelt que colocou como grande inimigo do estado o medo: "Permitam-se afirmar minha crença inabalável de que a única coisa que devemos temer é o próprio medo" (BAUMAN, 2008, p.7). 
mobilidade devido a seu alto capital e pleno acesso aos meios de transporte e de aparatos tecnológicos, aparentemente teriam pouco a temer, visto que tem a poderosa arma do globalismo no seu lado. Com A globalização negativa, as obrigações fiscais da 'superclasse' se tornam quase que voluntárias, a grande mobilidade entre diferentes localidades do mundo permite que estes afortunados possam, no menor sinal de desconforto, se deslocar livremente. Esse foco no medo dos perigos para a proteção pessoal afasta os olhos dos oprimidos dos medos essenciais, e assim, as atividades produtivas dos altos cidadãos podem fluir livremente, sem maiores percalços. (BAUMAN, 2008, p. 207).

No entanto, não podemos desconsiderar o crescente consumo, por parte desta "superclasse", de produtos de proteção pessoal. A elite se esconde cada vez mais atrás de seus muros, criando ambientes fechados e exclusivos para membros de seu "nicho". Seus filhos percorrem condomínios fechados, shoppings selecionados e freqüentam escolas privadas com rigoroso sistema de segurança. Seus carros são blindados, suas casas protegidas por sofisticados sistemas de segurança, e assim por diante.

Ao sentimento de insegurança está normalmente ligado o ímpeto de defesa, o qual, em um contexto individualista e de descrença no papel do Estado como protetor, é concretizado através de mecanismos privados de proteção, tais quais: a contratação de seguranças pessoais, blindagem de carros, instalação de câmeras de vigilância, e assim por diante (BAUMAN, 2008, p. 172-173).

Acerca desse problema Bauman sustenta que a referida nova legislação criada pelos estados deram uma visibilidade aos terroristas que eles nunca conseguiriam conquistar sozinhos. Em seguida ele acrescenta que apesar da função declarada desses esforços legislativos e militares 
antiterroristas ser a aniquilação desses grupos de terror, existiria uma "função latente" que seria:

o esforço para mudar as autoridades do Estado de áreas que não podia, não ousava, nem pretendia efetivamente controlar para uma outra- onde seus poderes e sua determinação para agir poderiam ser espetacularmente demonstrados, para os aplausos do público. (BAUMAN, 2008, p. 1999)

Nessa "tarefa de encontrar sozinhos soluções individuais para um dilema socialmente produzido" , especificamente na área de segurança, traz consigo a idéia de deslocamento, pois os indivíduos tendem a buscar a segurança de seus corpos e as extensões destes, não contemplando a real fonte de suas agruras, que seria a ausência de "segurança existencial" (BAUMAN, 2008, p.180). Isto seria uma maneira de tentar, num contexto de mudanças constantes, estabelecer controle sobre algum elemento de suas vidas, elemento este que é visível palpável, concretizado em perigos passíveis de mais fácil combate. É a busca do que Bauman chama de "alvos substitutos para descarregar o medo existencial excedente." (BAUMAN, 2008, p. 185-186).

Para Bauman existem diversas fontes de medo na atualidade. Uma delas é o progresso, que, por muito tempo, foi uma idéia reconfortante e revestida de otimismo. No contexto de flexibilização das relações humanas, principalmente as de trabalho, e da imprevisibilidade dos perigos e do futuro, o progresso passa a ser uma idéia aterradora. Os indivíduos, com o dever constante de cuidado e luta pela manutenção de sua condição de consumidor e participante do mercado produtivo, se vêem assombrados pelo fantasma da exclusão, a qual pode ocorrer a qualquer tempo, e por qualquer deslize. (BAUMAN, 2008, p. 181).

\subsubsection{Exploração econômica do medo}

Outra questão importante é a exploração econômica do medo, que é exercida ativamente não só pelos mercados de materiais e acessórios de 
segurança e proteção pessoal já mencionados ${ }^{13}$ como também pelas indústrias de medicamentos, e até do lançamento de programas, livros e filmes de "auto- ajuda".

Ao falar da psicopatologia da pós-modernidade, Vera Malaguti Batista fala de como esta se encontra "enraizada nos holofotes do espetáculo e na cultura do narcisismo", na qual se espera que os indivíduos, como seres orgânicos -biológicos que tem de "se virar" sozinhos, funcionem corretamente. A busca por resultados imediatos e eficientes para as doenças ou disfunções psicológicas leva ao abandono de tratamentos terapêuticos de longo prazo em benefício ao uso de medicamentos ${ }^{14}$.

Vera Batista ao citar Joel Birman, fala de como o tratamento por meio de medicamentos, tanto para depressão quanto para toxicômanos, afeta diversas funções do cérebro, prejudicando a memória e a atenção. Este visa, em última instância, "a anulação e o silêncio da história de uma existência e, conseqüentemente, a eliminação da história do sujeito, reduzido à funcionalidade orgânica.” (BATISTA, 2003, p.89-91). A manifestação de desejo ou singularidade é vista, por muitos destes terapeutas como um agravamento do quadro do paciente. Diante do que já foi exposto não é de se surpreender que esta prática de tratamento psicológico através de remédios seja amplamente ministrada para membros dos grupos marginalizados.

13 Quanto ao mercado de produtos de segurança privada, e o estímulo de compras através de campanhas publicitárias que exploram as catástrofes terroristas, Bauman cita o exemplo das SUVs (Sport Utility Vehicles) que são carros, com alto nível de consumo de gasolina, paramentados e construídos fazendo alusão direta aos carros usados por militares (os Hummers) para supostamente oferecer maior proteção aos passageiros. O comprador deste carro está reconhecendo, em alguma ordem, que o espaço urbano é uma linha de combate, marcado pela imprevisibilidade e o perigo. (BAUMAN, 2008, pg.187).

14 É importante observar que a psicanálise trabalha com a análise e reconhecimento do desejo, a valorização da memória e das singularidades que constituem um paciente específico, ao passo que a psiquiatria biológica através do uso de medicamentos pesados acaba por neutralizar o desejo, prejudicar a capacidade de lembrança dos pacientes, ocasionando uma homogeneização destes. (BATISTA, 2003, p. 87-89). 
Para Birman, os medicamentos se transformam em "verdadeiros fetiches para a proteção contra a dor de existir". Esse torpor trazido pelas drogas, que altera a consciência do paciente de forma que ele não sinta, ao menos durante a duração da dose, os terrores que assombram a existência pós-moderna, vai de encontro ao que a psicanálise propõe, pois esta parte do pressuposto que o sujeito tem que passar pelo mal-estar para levar o sujeito à simbolização do seu sintoma, da sua dor. A partir do momento que este não mais sente ansiedade e angústia, ele perde de vista a solução ou ao menos o melhor entendimento de seus problemas, não mais reflete sobre sua história de vida e todos os fatores que podem ser causadores de seu problema. E este histórico individual de conflitos, desejos, e frustrações é que constituem a singularidade dos indivíduos. Pode-se dizer, então, que o fim do mal-estar seria "algo assim como o fim da história" visto que a memória seria a "única instância a romper com a lógica homogeneizante da civilização”. (BATISTA, 2003, p.91-93)

A literatura de auto-ajuda segue essa mesma lógica de generalização e uniformização dos sujeitos, pois contém orientações abstratas e abrangentes acerca do sofrimento e das dificuldades humanas. (BATISTA, 2003, 91-93).

Esta busca de satisfação imediata é condizente com o que já foi exposto sobre a sociedade contemporânea como uma sociedade de "crédito", que busca o prazer imediato e a protelação máxima do sofrimento futuro. Logo, não há nada de espantoso na alta lucratividade da indústria farmacológica e das editoras de livros de auto-ajuda.

Bauman sintetiza bem a questão da utilidade da proteção social ao falar:

Enquanto a proteção pessoal se tornou um grande ponto de vendas, talvez $o$ maior, nas estratégias de marketing de mercadorias de consumo, a garantia da "lei e ordem", cada vez mais confinada à promessa de proteção pessoal, se tornou um grande ponto de venda, talvez $o$ maior, tanto nos manifestos políticos quanto 
nas campanhas eleitorais- ao mesmo tempo em que as ameaças à segurança pessoal foram promovidas à posição de grande trunfo, talvez $o$ maior, na guerra de audiência dos veículos de comunicação de massa, aumentando ainda mais o sucesso dos usos comerciais e políticos do medo. (BAUMAN, 2008, pg. 188).

A grande questão é que esta mesma estrutura de proteção individual que visa sanar as ansiedades e temores, é, no entanto, um lembrete constante da desordem que a fez necessária. Isto é, estes mecanismos visíveis de proteção privada reforçam a idéia, nas mentes inseguras, que se está vivendo em uma atmosfera desordenada e insegura. Desta maneira, os temores, uma vez instaurados na sociedade têm uma capacidade quase independente de se reproduzir e intensificar.(BAUMAN, 2008, p.173).

Esta capacidade de "auto-reprodução", no entanto, não é, por si só, perpétua e apenas pode ganhar esse caráter contínuo se os medos disseminados tiverem como fonte primária de força o que Bauman chama de "tremores existenciais". Aos tremores existenciais está ligada a idéia de imprevisibilidade e incapacidade de prevenção, a idéia de "golpes do destino" que atingem os seres humanos de surpresa, sem que estes estejam ou possam vir a estar preparados. Essa sensação de impotência e ignorância é historicamente uma fonte de insegurança e ansiedade. A diferença que Bauman aponta para os medos atuais é a questão do "desacoplamento entre as ações inspiradas pelo medo e os tremores existenciais que geraram os medos" ou seja, o" deslocamento dos medos" para áreas cotidianas com grande visibilidade que pouco têm em comum com as reais causas das ansiedades. (BAUMAN, 2008, p.174)

$\mathrm{Na}$ realidade contemporânea grande parte dos perigos estabelecidos não é passível de confirmação da população em geral, não possuem nenhuma forma direta de comprovação, e, por isso, estes podem ser facilmente inseridos e retirados da subjetividade pública (BAUMAN, 2008, p. 189). Neste contexto, podem-se dar diversos usos para o medo. Como já foi visto, o medo pode ser um mecanismo de legitimação do Estado, ou um 
estímulo poderoso ao consumo de produtos de proteção pessoal e de medicamentos e literaturas de auto-ajuda, também pode (ao ser manipulado) se utilizado para deslocar a atenção de problemas estruturais e essenciais para problemas pontuais e visíveis (sendo assim uma arma apaziguadora das insatisfações, que camufla os verdadeiros problemas da sociedade e governos contemporâneos e seus respectivos causadores).

Depois de mapear os principais papéis do medo na realidade pósmoderna, é fundamental mencionar a questão da construção de um imaginário social do medo dentro de uma lógica de espetáculo e de primazia da estética. No próximo capítulo exploraremos esta questão, focando a análise no papel da mídia como produtora de imaginário. A partir desta perspectiva, trataremos brevemente também da conjuntura específica do Rio de Janeiro, a atuação da imprensa e também a difusão do medo em geral nesta localidade. 


\section{3- Medo e Imaginário Social}

Durante a passagem do século XX para o XXI se consolidou o que Gizlene Neder, citada por Vera Malaguti, chama de uma produção imagética do terror, corporificada nas mídias impressas e digitais. $\mathrm{O}$ medo passa a ser encarado como um "projeto estético" no qual imagens provocativas, veiculadas por meios diversos de comunicação, fomentam o sentimento de insegurança e ansiedade de diversos integrantes da sociedade (BATISTA, 2003, p.75-76). Imagens essas que capturam condutas transgressoras praticadas tipicamente pelos grupos marginalizados da sociedade que, por serem praticadas no espaço público, são dotadas de grande visibilidade e portanto de fácil registro. Estes agentes marginalizados e retratados na mídia passam a representar a corporificação dos medos e da ameaça a lei e a ordem. São alvos de repulsa e reprimendas por parte dos demais setores da sociedade e principalmente das políticas de segurança, como já foi explanado no capítulo anterior.

$\mathrm{Na}$ sociedade inserida no capitalismo de consumo, a estética reproduz a ordem e a hierarquia social conveniente aos grupos dominantes. Vera Malaguti, ao citar Terry Eagleton, destaca a estetização como instrumento de produção de amnésia, no sentido de que teria a força de apagar a memória de idéias radicais que impusessem ameaças à ordem estabelecida. A estética seria uma "categoria burguesa" instrumental para produzir um modelo de subjetividade tal que serviria de maneira precisa à classe média para esta praticar suas "operações materiais" (BATISTA, 2003, p. 75-77).

\section{1- Construção de um Imaginário social do medo}

Neste prisma da estética e produção de imagens, Felipe Corrêa, em sua dissertação de mestrado sobre os imaginários do medo, escolhe como definição de imaginário a acepção dada a por Jean-Jacques Wunenburguer: 
...imaginário [é] um conjunto de produções, mentais ou materializadas em obras, com base em imagens visuais (quadro, desenho, fotografia) e lingüísticas (metáfora, símbolo, relato), formando conjuntos coerentes e dinâmicos, referentes a uma função simbólica no sentido de um ajuste de sentidos próprios e figurados (CORRÊA, 2008, p. 9).

Felipe Corrêa analisa especificamente a construção de imaginário através da imprensa, a qual, por meio de suas notícias e fotografias provocativas, sua credibilidade e alcance, consegue estabelecer uma atmosfera de insegurança. Ela o faz tanto pela utilização de notícias que focam na guerra com conflitos armados do tráfico, como naquelas que narram os perigos cotidianos. $\mathrm{O}$ grande método, apontado pelo autor, para inculcar esse medo na sociedade é dar visibilidade às situações de suposto perigo. Isso é feito através da repetida veiculação de notícias desses dois gêneros com graus de dramaticidade variantes, criando representações do real que são sedutoras e com alto potencial de convencimento.

Felipe Corrêa atesta que o melhor alvo para as câmeras e teclas perspicazes da imprensa são as práticas transgressoras efetuadas no espaço público, preferencialmente de natureza violenta. Estas práticas visíveis costumam ser perpetradas pelos grupos marginalizados da sociedade, predominantemente, o homicídio, o roubo e o tráfico, haja vista que os crimes normalmente praticados pelos ricos, os de colarinho branco, são praticados em âmbito privado, por meio de computador ou em escritório fechados, através de ligações e acordos confidenciais e depósitos em bancos estrangeiros.

Corrêa cita Rondeli para demonstrar como a imprensa, ao criar representações sociais sobre o crime produz significados que:

...não só nomeiam e classificam a prática social, mas, a partir desta nomeação, passam mesmo a organizá-la de modo a permitir que se proponham ações concretas em relação a ela. Portanto, o modo como a mídia fala sobre a violência faz parte da própria realidade da violência: as interpretações e os sentidos sociais que serão extraídos de seus atos, o modo como certos discursos sobre ela passarão a circular no espaço 
público e a prática social que passará a ser informada cotidiana e repetidamente por estes episódios narrados. Revela-se, aqui, o caráter estruturador dos discursos (CORRÊA, 2008, p. 15)

A mídia, como produtora de discurso, ao reiterar certas afirmativas pode instituir um imaginário social do medo. Suas práticas podem ser vistas como "narrativas produtoras de sentido e de ordenamento, de afirmação de fronteiras, de divisões, que acabam por guiar a ação e o pensamento dos agentes sociais.” (CORRÊA, 2008, p.17).

Desta forma, os jornais colaboram de maneira expressiva para a formação de uma "cultura do medo". Como bem diz Sergio Graziano Sobrinho, para entendermos esta questão da formação de um imaginário, é importante se considerar o medo não como um "medo individual", que corresponde à ansiedade gerada por uma ameaça real ou desconhecida, mas sim um medo "socialmente partilhado" que manipula o senso comum, possibilitando a dominação através da construção e moldura do imaginário.(SOBRINHO, 2005, p. 215).

Citando Marilena Chauí, Graziano Sobrinho define as características do senso comum que é objeto de manipulação. Este seria "subjetivo" (por expressar opiniões detidas por indivíduos ou conjuntos), "qualitativo", "heterogêneo", “individualizador", "generalizador”, teria a constante tendência a estabelecer uma relação de causa e efeito entre os fatos, tenderia a projetar nos objetos ou no mundo suas ansiedades e temores diante do desconhecido, cristalizariam preconceitos condicionando a visão dos indivíduos relativa aos acontecimentos.(SOBRINHO, 2005, p.216).

Sérgio Graziano fala também da atuação de um imaginário social "ideologicamente efetivado" tanto pela mídia como pela família e a religião. Ao citar Marilena Chaú, ele fala dos processos utilizados pela ideologia para alcançar seus objetivos: a inversão das causas e efeitos de determinados fatos e fenômenos criando falsas causalidades; a produção do 
imaginário social por meio de uma "imaginação reprodutora", utilizando imagens e criando representações da realidade, moldando a maneira que a população deve pensar, agir e reagir diante de determinados acontecimentos; e o silêncio, operando como o "inconsciente descrito pela psicanálise".(SOBRINHO, 2005, p. 220).

A sociedade tende então a interpretar fatos de acordo com a ideologia vigente, que normalmente corresponde ao discurso do grupo dominante o qual tem suas idéias disseminadas e incorporadas pelos demais cidadãos como sendo a maneira correta de se pensar. Assim, os grupos dominantes conseguem exercer dominação sobre os demais, através de uma ideologia que cria um imaginário, que, no caso da sociedade atual, muitas vezes consiste em um imaginário do medo.(SOBRINHO, 2005, p.220). O medo é, pois, um mecanismo de dominação amplamente utilizado na contemporaneidade, como já vimos em capítulos anteriores.

Ao falarmos de imaginário do medo, estamos lidando com o simbólico, com narrativas "que atribuem características e que lançam pontos de mediação entre ações e significações sociais." (CORRÊA, 2008, p. 17). Para Corrêa, esse imaginário depende diretamente de como se atribuiu significado a questões e conjunturas econômicas e sociais, e de como se retratou, divulgou e elegeu os perigos, já que sem um perigo declarado, mesmo que vago, dificilmente há medo.

É importante qualificar também qual é a violência a qual é alvo do medo urbano. A violência na sua acepção pura e simples, por mais que cause ferimentos e fatalidades não representa uma ameaça suficiente para alimentar o imaginário do medo. Segundo Felipe Corrêa, a violência precisa ser divulgada, espetaculizada através de vívidas imagens. Com tal caráter, a violência passa a ser experimentada de maneira freqüente sem que aqueles que a experimentam precisem sofrer danos diretos. Essa concepção da 
violência performática é bem capturada pela citação feita por Corrêa de Schröder \& Schmidt:

\begin{abstract}
Atos violentos são, provavelmente, mais eficientes por sua demonstração de poder e legitimidade, do que por suas conseqüências físicas. Em outras palavras, a guerra como um processo de longa duração só culmina em reais atos de violência ocasionalmente, e ambas as partes têm indivíduos que não são confrontados com a violência real de nenhuma maneira, mas a violência como performance estende sua eficácia pelo espaço e pelo tempo, e leva sua mensagem para outras pessoas que, em sua maioria, não são afetadas fisicamente pela violência. Além disso, a qualidade performática faz da violência uma experiência diária (com todas as conseqüências para a sociedade) sem que ninguém sofra, de fato, danos físicos todos os dias."(CORRÊA, 2008, p. 18).
\end{abstract}

A mídia tem hoje influência em vários setores da vida social, desde a saúde até a estética corporal e a moda. Esta, substituindo o antigo papel da literatura é o atual "árbitro do gosto, dos valores e do pensamento." (CORRÊA, 2008, p. 21). Este apelo é ligado ao fato da mídia trabalhar com representações do real, discursos travestidos de realidade e objetividade. A "suposta narração objetiva do real” da linguagem da mídia é extremamente sedutora por evocar e administrar "as paixões humanas". (CORRÊA, 2008, p.21).

A cidade do Rio de Janeiro é localidade propícia para se verificar os usos do medo e o papel da mídia na criação de um imaginário. Em um ambiente como o da cidade carioca, rico de delitos e transgressões praticadas em espaço público, a imprensa mantém como uma constante o elemento do medo nas suas notícias. Ela reforça a opinião das políticas duras de controle social centradas nas ações policiais invasivas e de alto nível de agressividade como solução para a violência e a desordem urbana.(CORRÊA, 2008, p.15).

3.2- O Medo na Cidade do Rio de Janeiro, uma perspectiva de Vera Malaguti Batista 
Em seu livro O Medo na Cidade do Rio de Janeiro: Dois tempos de uma história Vera Malaguti Batista traça um histórico do uso do medo "como mecanismo indutor e justificador de políticas autoritárias de controle social" (BATISTA, 2003, p.23) em dois momentos da história carioca: o século XIX no contexto das revoltas escravas e da abolição da escravatura, e na conjuntura a partir das campanhas eleitorais de 1992. Tal análise é esclarecedora da questão da construção de um imaginário do medo, que estamos tratando.

$\mathrm{Na}$ época da escravidão na cidade do Rio de Janeiro, com as freqüentes ameaças de revoltas, a solução encontrada pelos governantes e senhorios não foi a abolição mas sim a delimitação precisa de um inimigo, um elemento de fora, sobre o qual se poderia instaurar um regime de controle muito rigoroso: o escravo, liberto ou não.(BATISTA, 2003, p. 28) Desta maneira, era necessário estabelecer um medo desproporcional para a manutenção do controle das camadas insatisfeitas da sociedade escravocrata.

Vera Batista aponta a evangelização como fundamental no processo de colonização. Através do uso de uma "pedagogia do pecado, da morte e da culpabilização" a evangelização neutralizava ou, ao menos, acalmava os ânimos sediciosos (BATISTA, 2003, p. 30). A igreja recorria ao imaginário da morte para firmar seu poder. A autora descreve os sistemas de exploração da morte, já em voga no séc. XVI. Este consistia em: "Um sistema econômico (o comércio das missas e indulgências), sistema político (as recompensas e os castigos do além, como garantia de ordem na terra)".(BATISTA, 2003, p. 31)

Para Vera Batista, a ideologia que rege a maior parte das políticas de controle social no Brasil era, e ainda é, permeada por "fantasias absolutistas" de controle social com caráter policial, nas quais a obediência 
era indispensável (BATISTA, 2003, p. 32). A autora relata que a constante incorporação de pressupostos teóricos e ideológicos no Brasil - colônia era feita, e o é até os dias de hoje, sempre de maneira que não abalasse a hierarquização da sociedade.(BATISTA, 2003, p. 32). A autora menciona a figura do chefe de polícia Eusébio de Queiroz, que via a escravidão como limitadora à instauração de políticas modernas no policiamento urbano e, por isso, propôs uma rígida estratégia de controle do deslocamento dos escravos além de seu confinamento nas propriedades senhoriais. A este tipo de atuação da polícia Vera Batista compara a atuação policial de hoje nas favelas, indicando a reminiscência do "legado absolutista" e "da obediência cadavérica" observados desde os primórdios da história da colonização Brasileira.(BATISTA, 2003, p. 32).

O trânsito e a permanência constante de classes hierarquicamente inferiores no espaço público, visível e comum, geravam para a elite, e geram ainda hoje, "fantasias de pânico do caos social" (BATISTA, 2003, p. 34). A preocupação quase obsessiva com a manutenção da ordem é incompatível com a tolerância ao "outro". Diante de uma insegurança instaurada e um inimigo interno delimitado e demonizado, "sociedades assombradas produzem políticas histéricas de perseguição e aniquilamento" (BATISTA, 2003, p. 26).

No caso do século XIX, esses "outros" eram os escravos, os quais eram objetos do "medo branco" das constantes ameaças de rebelião. A década de 30 do séc. XIX foi particularmente turbulenta, marcada por diversas ameaças de insurreições e revoltas, por discursos sediciosos que percorriam a maior parte do país. Algumas revoltas da época citadas por Vera Batista foram: A Revolta dos Malês na Bahia, a Revolução Farroupilha no sul do país, a Revolta da cabanagem no Pará , entre outras. Manifestações revoltosas continuariam a ocorrer por algumas décadas, 
cumpre citar os movimentos da Sabinada, Balaiada e Praieira. (BATISTA, 2003, p. 126).

O temor frente à figura do escravo foi agravado pelo que a autora menciona ter sido o "processo de formação da cidade negra", entre 1830 e 1870, o qual levou o medo dos levantes a ser maior do que a probabilidade concreta destas insurreições acontecerem. Essa atmosfera apreensiva engendrou a criação de uma "cidade armadilha com sua paranóia de defesa à propriedade" no Rio de Janeiro. (BATISTA, 2003, p.36) Segundo Vera Batista esse "medo branco" aumenta com o fim da escravatura e a declaração da república, trazendo uma configuração republicana eivada do vício da "desigualdade legítima" que advém da sociedade escravista. Com a abolição, os ânimos ansiosos das elites se exacerbaram e com isso veio a estratégia de "suspeição generalizada" contra os negros e os pobres, sendo os primeiros considerados "suspeitos preferenciais" (BATISTA, 2003, p. 38). A autora aponta ainda para a origem do conceito de "classes perigosas", que se instituiu com as políticas de eliminação de habitações coletivas e de epidemias por meio de força policial. Esta classe seria perigosa por ser destituídas de bens, por ter uma posição desafiadora das políticas urbanas de controle e por ser potencial propagadora de doenças.(BATISTA, 2003, p. 37). Vera Batista alega que as fantasias das elites acerca da abolição percorriam diversos caminhos, desde a lembrança das revoltas no Haiti até as construções de medo em cima do voodoo e outras práticas da cultura africana.

Vera Malaguti Batista observa a permanência até a atualidade do discurso médico-policial, de fundo biológico, nos países europeus, nos Estados Unidos e principalmente na América Latina. Medidas que selecionam e destacam a camada mais pobre e vulnerável da sociedade, notadamente as chamadas minorias étnicas (que nem sempre são minoritárias), como se estas fossem intelectualmente inferiores e tivessem a 
predisposição natural para a desordem e o delito. No caso específico da América Latina, ocorreu o que a autora chamou de "seqüestro institucionalizado de milhões de seres humanos", o que se expressava não só nas prisões coloniais e nas prisões em geral de tempos seguintes, como também nas políticas genocidas de contenção perpetrada contra índios, negros, pobres e criminalizados ao longo da história.(BATISTA, 2003, p. $95)$.

Para ilustrar essa tendência excludente e aniquiladora das políticas de controle dos setores desfavorecidos da sociedade Vera Batista separa historicamente em dois blocos as prisões: as prisões como fábricas de disciplina (sécs. XVIII e XIX) e as prisões como fábricas de exclusão (sécs. XX e XXI). O primeiro bloco coincide com a revolução industrial e a conseqüente necessidade de mão de obra livre e operária, no qual as prisões eram derivadas das working-houses onde os párias sociais eram recolhidos para trabalhar. Já no segundo bloco, a prisão adquire a função precípua de excluir, alienar definitivamente integrantes da sociedade que representem ameaças ao sistema produtivo e à ordem (BATISTA, 2003, p.99), os “cidadãos negativos" (BATISTA, 2003, p. 102) (antes os escravos e hoje as massas marginais) como bem nomeou Nilo Batista, ou os desaparecidos de nascença (muitos nem sequer foram registrados e são muitas vezes ignorados nas políticas sociais) como os chama Vera Malaguti Batista, (BATISTA, 2003, p. 106).

Desde o regime ditatorial no Brasil as campanhas de pânico social propagadas pela mídia e discursos oficiais propiciaram a instauração do autoritarismo e de uma política de extermínio. Da mesma forma, o imaginário construído em torno do tráfico de drogas e a juventude pobre e negra, contaminado com o darwinismo social, trouxeram uma representação deste setor da sociedade como sujos, vadios, agressivos e naturalmente maus, justificando ou ao menos tornando aceitáveis ou admissíveis (com 
baixo nível de reprovação moral) diversas ações violentas e agressivas da polícia e até da sociedade em geral.(BATISTA, 2003, p. 102-103). Vera Malaguti Batista também aponta a guerra contra o tráfico como marco de transição de um modelo sanitário para um modelo bélico. O discurso de guerra contra o tráfico, guiado pela busca cega pela ordem e segurança a qualquer custo, levam a relativização da noção de direitos humanos. Por muitas vezes, então, deixando correrem basicamente impunes as práticas de tortura e violência contra os membros do tráfico, e, muitas vezes contra os jovens das favelas em geral. (BATISTA, 2003, p. 103-104).

O tema central das campanhas eleitorais, assim como as grandes manchetes dos jornais, costuma girar em torno da questão da criminalidade e da segurança. O imaginário do medo e o sentimento de insegurança pedem por políticas penais de emergência (como já foi exposto no primeiro capítulo) e acabam por legitimar práticas desumanas por parte da polícia, trazendo de volta até generais da ditadura para comandar os esquadrões de execução de negros e pobres nas favelas, massacres estes que muitas vezes passam despercebidos pela mídia.(BATISTA, 2003, p. 104). A volta da tortura é vista por Vera Batista como um resgate dos rituais de "execução do herege", espetáculo típico do sistema penal canônico.

Para ilustrar a biologização do mal, no qual o problema social é visto como doença, e os atores transgressores são vistos como animais, Vera Batista destaca diversos trechos de artigos de jornais, editoriais, discursos políticos dos últimos anos. O discurso que animaliza o mal costuma envolver as idéias de limpeza e extermínio. Exemplo de termos animalizantes usados em artigos e editoriais de jornais de grande circulação no Rio são adjetivos como "insetos", "animais", "monstros", "feras", “cupins", "répteis irrecuperáveis", "sub-raça”, "bandos”, “vírus”. O discurso higienista se faz notar através da utilização de termos como "lixo humano", "veneno sem antídoto", "guerra suja", "lixo humano", "Chacina 
ou faxina?”, “partes necrosadas da sociedade”. (BATISTA, 2003, p. 113116)

Vera Batista relata como as chacinas e práticas violentas da “Operação Rio" são vistas como políticas de saneamento e limpeza. Tais discursos criam um ambiente de hostilidade contra os setores marginalizados da sociedade, uma urgência para aniquilar eficientemente essa fonte de insegurança e ansiedade no coração dos "bons cidadãos”.(BATISTA, 2003, p.117). A frase que Vera Batista cita tirada de uma entrevista do jornal Folha de São Paulo em 2000, expressa esse imaginário com clareza. Garotinho, ao ser perguntado sobre a morte de seis criminosos pelas mãos da polícia carioca, afirma:

Não houve chacina. Houve a morte de seis bandidos procurados pela polícia. É diferente quando morre uma pessoa de bem, um trabalhador. Eram seis bandidos procurados pela polícia. Isso é normal. (BATISTA, 2003, p. 118-119).

Esta frase demonstra não só o descaso e a violência com que são tratados os praticantes de delitos mas também uma naturalização das práticas duras e violentas de combate à criminalidade na cidade carioca. $\mathrm{O}$ discurso dominante faz parecer normal o ato de matar seis bandidos procurados pela polícia, com a justificativa de serem criminosos e não pessoas de bem.(BATISTA, 2003, p. 119).

\subsection{Histórico da pobreza no Rio de Janeiro}

Para melhor entender o contexto social atual, é interessante se traçar um histórico desde os últimos anos do século XIX até o final do século XX. Para tanto, é usado como base o artigo de Lícia Valladares: "Cem Anos Pensando a Pobreza (Urbana) no Brasil" que analisa três cortes temporais que ilustram bem as mudanças na estrutura social: a virada do século XIX para o XX, as décadas de cinqüenta e sessenta, e as décadas de setenta e oitenta . 
A autora pontificou as grandes questões da virada do século XIX para o XX como sendo: o discurso médico-higienista, a preocupação com a manutenção da ordem e o controle dos trabalhadores, e o discurso que defendia submissão dos escravos libertos e imigrantes pobres à ordem do trabalho. Neste tempo, o Rio tinha um saneamento deficiente e era um foco de epidemias. As autoridades, diante da flagrante insalubridade urbana, passaram a agir com um ímpeto de "desodorização do espaço urbano", e passaram a realizar políticas de "medicalização da cidade", através da implementação de diversas medidas de desinfecção de ambientes e combate a doenças, que culminaram com a campanha sanitária de Osvaldo Cruz.(VALLADARES, 1991, p. 85).

Segundo Lícia Valladares, as medidas de sanitarização implicavam em uma interferência direta e física na vida e privacidade das classes mais desfavorecidas, e levaram ao aumento do aborrecimento com as políticas públicas, o qual já vinha sendo e expressado em episódios sediciosos como a Revolta do Vintém (1880) e a quebra dos lampiões (1882).

O campo de protesto era a rua e o contingente de descontentes era bem amplo: e englobava operários, comerciantes, desempregados, e mendigos. Apesar de todos esses grupos participarem das manifestações, apenas estes dois últimos setores (os considerados vadios) foram taxados como causadores dos tumultos, como pertencentes a uma classe perigosa. Isso porque a lógica moralizante da época era o trabalho, logo, o operariado não poderia carregar este estigma. Lembrando que este era um contexto no qual, com o desenvolvimento industrial, a necessidade de mão de obra era premente e o trabalho ainda era visto como indigno por carregar os estigmas do escravismo. (VALLADARES, 1991, p. 88-93). Desta forma, a conjuntura da época era orientada por uma dicotomia: de um lado o mundo da fábrica, do trabalho, da moral e da ordem; de outro o mundo amoral, vadio e caótico no qual a rua era o prolongamento do cortiço. Os excluídos 
do universo fabril, que eram em sua grande maioria negros e pobres, eram considerados uma “classe perigosa”. (VALLADARES, 1991, p. 87).

Já nas décadas de cinqüenta e sessenta do século passado, a produção estava inserida em um contexto não mais agro-exportador e sim urbanoindustrial. A autora aponta para o fato de os centros urbanos terem se multiplicado (“de 74, em 1920, eles passam a 96. em 1950 e a 172, em 1960”) e difundido ao longo de outras áreas, formando cidades com mais de vinte mil habitantes (VALLADARES, 1991, p. 94). Os grandes centros urbanos (como Rio de Janeiro, São Paulo, Belo Horizonte, Curitiba, Fortaleza, Salvador, e Recife) encontravam-se inflados, e, alguns destes de maneira ainda mais acentuada, devido a movimentos de migração intraestaduais. Segundo a autora, tal desproporção de distribuição populacional, aliada a diferenças de capacidade e desenvolvimento econômico de região para região, ocasionou grandes desequilíbrios. Uma das maiores conseqüências dos desequilíbrios foi a insuficiência da oferta de empregos, o que ocasionou um crescimento desmedido do setor terciário de prestação de serviços e agravou o caos e precariedade urbanos.(VALLADARES, 1991, p.95) A autora cita dados estatísticos para ilustrar a emergência do setor terciário como fonte de trabalho (cerca de $26 \%$ da população), demonstrando a diminuição da parcela da população empregada pelo setor primário (apenas 60\% eram empregados neste setor). (VALLADARES, 1991, p. 94).

Lícia Valladares afirma que o desenvolvimento econômico deste período tinha como característica uma dualidade do mercado de trabalho: um era moderno e gerador de empregos e o outro era tradicional e gerava subemprego. Ela afirma, também, que o estigma escravista do trabalho havia sido superado, e agora o desejo de se integrar no mercado de trabalho era comum. $\mathrm{O}$ grande problema era que muitos para trabalhar tinham que 
recorrer ao subemprego (cuja remuneração era baixíssima) e, muitas vezes, ao exercício de atividades informais ou, até mesmo, até ilícitas.

$\mathrm{Na}$ década de trinta, a legislação trabalhista começou a ser instaurada e com ela também vieram a Carteira de Trabalho e Previdência Social e o salário mínimo, os quais são, segundo Lícia Valladares, “institucionalizadoras de diferenças já existentes no mercado de trabalho, [estas] reafirmariam a separação entre assalariados e não-assalariados, entre empregados de um lado e subempregados de outro, valorizando a figura do trabalhador." (VALLADARES, 1991, p. 97-98).

Desde o início do século, as favelas passaram a emergir, primeiramente no Rio de Janeiro, Recife e Belo Horizonte e, de maneira mais tardia, em São Paulo. Lícia Valladares aponta que na virada do século a pobreza tem, como "matriz espacial", o cortiço carioca, visto como berço do crime e do vício da vadiagem espaço a ser erradicado pelas políticas modernizadoras do prefeito Pereira Passos. Na década de cinqüenta, as favelas, novo lugar de moradia dos setores populares, se encontram configuradas no espaço urbano e em processo de expansão. A autora atribui essa favelização à urbanização acelerada e ao modelo de desenvolvimento econômico desigual. A favela é vista, assim como o cortiço era, como "síntese da não integração", "lugar insalubre (...) verdadeiro câncer necessitando ser extirpado do tecido urbano." (VALLADARES, 1991, p. 98)

$\mathrm{Na}$ década de sessenta, época em que o critério de renda estabelecido pelo banco mundial já estava inserido na definição de pobreza, também surgem as COHABS, que tinham como alvo famílias com renda de até três salários mínimos que foram objeto de políticas de remoção nas favelas. A idéia era alocá-las em conjuntos habitacionais de casas ou edifícios populares com qualidades diferentes, de acordo com a renda familiar (havia uma segmentação até mesmo nestes). (VALLADARES, 1991, p.100). Lícia 
Valladares apresenta o uso do critério da renda como segregador, pois diferencia as pessoas que têm direito e acesso a programas sociais e cestas básicas daquelas que não têm. A autora comenta, também, sobre o valor dado aos "ganhos auferidos pela participação na atividade econômica", ou seja, a remuneração recebida pelo trabalhador e a capacidade de suprir suas necessidades básicas e de consumo com o salário pago.

$\mathrm{Na}$ medida em que a pobreza vai se tornando mais visível e disseminada na sociedade brasileira, ela se torna uma questão considerada relevante nos planos de discussão. Nesta época, os cientistas sociais passaram a discursar com mais ênfase sobre ela por meio de artigos e estudos. A partir daí, uma corrente de acadêmicos relativiza a visão da responsabilidade pela pobreza, que antes era considerada individual, considerando a influência de determinantes externos no processo de empobrecimento, atribuindo ao capitalismo a marginalização dos setores pobres que compunham esse contingente imenso de mão de obra desqualificada. (VALLADARES, 1991, p. 96-97).

Na década de setenta, o Brasil era considerado a oitava economia mundial e tinha sofrido grandes mudanças em sua estrutura econômica. $\mathrm{O}$ processo de industrialização brasileiro encontrava-se bem firmado: muitas empresas tinham dimensão internacional ou até multinacional e eram dotadas de feições oligopolistas; o mercado de consumo de bens duráveis encontrava-se mais dinâmico; os setores de produção de insumos e bens de capital e de serviços estavam em crescimento.(VALLADARES, 1991, p.101)

Lícia Valladares fala de uma urbanização que continua acelerada e superior ao crescimento demográfico, a primeira cresceu em média 4,5\% enquanto a segunda só cresceu 2,4\%. A concentração da rede urbana no eixo Rio-São Paulo diminuiu, ficando em apenas 28\%. Estas grandes 
cidades começaram a passar por um processo de metropolização que foi, por sua vez acompanhado por uma periferização que Lícia Valladares define como "processo de segregação espacial da classe trabalhadora, empurrada cada vez mais para longe da área central da cidade, confinada em espaços marcados pela escassez de serviços urbanos e equipamentos de uso coletivos." (VALLADARES, 1991, p.102-103). Fenômeno este resultante do empobrecimento crescente das camadas mais desfavorecidas e dos trabalhadores como um todo, o realocamento de diversas famílias por programas sociais para áreas distantes dos centros urbanos. E o que a autora chama de "expulsão indireta" da população através de um aumento na carga tributária municipal e do custo de aluguel, além da especulação imobiliária. 15

A autora fala do movimento de remoção de favelas na década de oitenta no Rio de Janeiro. Ela diz que cerca de oitenta favelas foram removidas e as famílias colocadas em áreas periféricas. O custo da moradia nas favelas também se apresentou cada vez mais crescente, além de as favelas que permaneceram ter um crescimento mais controlado e verticalizado (através de construção de prédios). Para melhor ilustrar o contexto das favelas na década de oitenta cabe citar alguns dados estatísticos separados pela autora: "Levantamentos realizados pela IPLANRIO dão conta em 1980 da existência de 376 favelas e 427 loteamentos irregulares, dois dos quais cerca de $60 \%$ surgiram na década de 60-70, paralelamente à diminuição da taxa de crescimento da população favelada que passou de 97,9\% em 1960 a 68, 7\% em 1970 e 27, 8 e, 1980." (VALLADARES, 1991, p.103).

\footnotetext{
15 A respeito deste processo, a autora acrescenta que este consiste em "o crescimento rápido e desordenado das franjas metropolitanas a partir de processos de parcelamento do solo levados a cabo por pequenos e médios agentes imobiliários que se especializam em 'driblar' a legislação urbanística, criando loteamentos irregulares, muitas vezes clandestinos." (VALLADARES, 1991, p. 102-103).
} 
Lícia Valladares aponta também para o aumento da convivência da abundância com a miséria e do número de inseridos no mercado informal, o qual se consolida e se espalha até para ruas consideradas nobres em algumas cidades. Este trabalhador informal faz parte da divisão do trabalho e é chamado de trabalhador, mesmo exercendo atividades em condições precárias e instáveis. A pobreza agora atinge maciçamente os trabalhadores, até mesmo muitos que estão regularmente empregados. Proliferam-se o trabalho infantil e o de idosos. Muitas famílias que se situam na linha da pobreza têm membros de sua família inseridos no mercado formal de trabalho. Essa pobreza generalizada passa a ser categoricamente associada com ameaça, perigo e com o crime, como já vimos anteriormente.

\section{4-Pesquisas sobre mídia, criação de imaginário, e sentimento de insegurança no Rio de Janeiro}

Para ilustrar brevemente sobre o papel da imprensa Brasileira, especificamente a carioca, na criação de um imaginário do medo e da insegurança, é interessante analisar dois artigos, um que versa sobre mídia e violência e é elaborado por pesquisadores do $\mathrm{CESeC}$, Centro de Estudos de Segurança e Cidadania da Universidade Cândido Mendes; e o outro que aborda o sentimento de insegurança nos bairros da cidade do Rio de Janeiro e é elaborado por pesquisadores do NUPESP, núcleo de pesquisa do ISP, Instituto de Segurança Pública que é uma autarquia vinculada à Secretaria de Segurança Pública do Rio de Janeiro. Devemos aqui colocar a ressalva de que o ISP representa até certa medida o discurso oficial, visto que é vinculado a Secretaria de Segurança Estadual, e deve ser olhado com cautela, como uma fonte de dados que não é inquestionável, mas é, todavia, ilustrativa do que já foi abordado no presente capítulo.

$\mathrm{O}$ artigo do CESeC Mídia e Violência-Como os jornais retratam a violência e a segurança pública no Brasil, elaborado por Silvia Ramos e 
Anabela Paiva, analisou 2514 textos jornalísticos de nove jornais, distribuídos em São Paulo ( Folha de São Paulo, O Estado de São Paulo, e Agora SP), Rio de Janeiro (O Globo, Jornal do Brasil e O Dia) e Minas Gerais (O Estado de Minas, Diário da Tarde, e Hoje em Dia ), ao longo de cinco meses do ano de 2004 (usando o método de semana composta ${ }^{16}$ ).

A análise é feita por meio de quesitos elaborados em um questionário detalhado que foca nos temas de "criminalidade; políticas de segurança; forças de segurança; sistema penitenciário; justiça; reações da sociedade civil; pesquisas e legislação." (RAMOS\& PAIVA, 2005, p. 8). Ramos e Paiva justificam a escolha do veículo impresso como objeto de estudo dizendo que este é ideal para se aferir "que temas estão sendo debatidos nos jornais, com que profundidade e abrangência, quais são os atores sociais envolvidos no debate e identificar possíveis novas tendências" e assim poder perceber como estas questões estão sendo retratadas para o seu público alvo que consiste em pessoas que "têm poder de decisão" e muitos são “formadores de opinião pública" (RAMOS\& PAIVA, 2005,p.6). Ou seja, as autoras provavelmente visaram pesquisar sobre a disputa e a formação de discursos dominantes na mídia impressa que representam o modelo que posteriormente irá influenciar a população em geral através da reprodução destes por outros meios de massa.

Ao analisar a totalidade de notícias sobre os temas selecionados, Ramos e Paiva viram que 48,2\% destas cobriam a violência localizada no estado do Rio. Os jornais cariocas tratavam majoritariamente da violência local (O Dia: 94,5\%; JB: 82,2\%; O Globo: 78\%), pouco abordando incidentes ou conjunturas violentas em outros estados. O jornal $O$ Globo foi

\footnotetext{
16 Tal método consiste no sorteio de: "7 dias de cada um dos meses pesquisados. Na medida do possível, os dias deveriam estar distribuídos de forma equânime pelas semanas reais componentes do referido mês; além disso, esta semana artificialmente construída deveria possuir os mesmos dias de uma semana real (uma segunda, uma terça, uma quarta, uma quinta, um sábado e um domingo). Ao final, nosso universo amostral correspondeu a 35 dias ou $22,88 \%$ de todos os dias do período." (RAMOS\& PAIVA, 2005, p. 8)
} 
visto como o noticiário que, comparado a jornais de igual porte: $O$ Estado de São Paulo e a , mais tinha notícias cobrindo a questão da violência em geral, além de ter também uma expressiva cobertura da violência no Rio (RAMOS\& PAIVA, 2005, p. 11). Tal foco no Rio de Janeiro colabora para uma concepção dele como "estado problema" da região sudeste, criando um imaginário de insegurança, principalmente dos moradores cariocas e fluminenses que vêem seu estado como o grande foco de violência no país. Silvia Ramos e Anabela Paiva apontam tal resultado como uma louvável tentativa de denunciar a criminalidade no estado mas também criticam o fato da cobertura extensiva do estado do Rio de Janeiro impedir que os leitores façam uma comparação informada com a violência experimentada nos demais estados do país.

A maioria das notícias encontradas estava situada nos cadernos de cobertura local $(83 \%)$ e detinham predominantemente o que as pesquisadoras classificam como um "enquadramento individualizado" $(82,2 \%)$, o que consiste em um ângulo de abordagem que foca na descrição de um acontecimento específico, pontual e individual, sem análises conjunturais ou estatísticas (RAMOS\& PAIVA, 2005,p. 11-12). Os noticiários de apelo mais popular mostraram ter uma incidência ainda maior de notícias com este enquadramento. ${ }^{17}$ As autoras ressaltam que cerca de $27 \%$ das notícias recolhidas consistiam em pequenas notas informativas, sem qualquer contextualização.

A questão de um quarto das notícias consistirem nesses "colunões" somada ao fato de quase nenhum artigo ter o foco na divulgação de dados estatísticos (apenas 1,4\%,) leva os leitores a ter uma noção distorcida da relação entre a ênfase e freqüência que se noticia atos violentos e o registro oficial de acontecimento destes (RAMOS\& PAIVA, 2005, p. 36). Os

17 Enquanto jornais como O Globo e Estado de São Paulo focaram respectivamente 69,2\% e $67,4 \%$ em notícias individualizadas, jornais de apelo mais popular como O Dia e Agora SP focaram respectivamente $88,9 \%$ e $88,8 \%$. (RAMOS\& PAIVA, 2005, p. 17). 
leitores acabam não tendo uma percepção muito distante do número real de delitos que ocorrem naquela determinada localidade. Cabe observar que, segundo as autoras, nos poucos artigos estatísticos que foram encontrados, a fonte quase exclusiva de dados são os aparelhos oficiais, sejam as secretarias de segurança ou a polícia (39\% e 6,4\% respectivamente) ou órgãos oficiais de estatística $(17,9 \%)$, deixando pouco ou nenhum espaço para estudos acadêmicos, os quais forneceriam um contraponto ao discurso oficial.

As pesquisadoras, apontam para o significado alarmante da baixa publicação de notícias de cunho opinativo e ou contextualizador que discutam o fenômeno da violência, suas causas, conseqüências, e possíveis soluções ("apenas 5,4\% dos textos apontaram causas, 7,3\% soluções e $6,4 \%$ conseqüências") (RAMOS\& PAIVA, 2005, p. 34). A falta de artigos desta natureza implica na visão dos acontecimentos delituosos "como uma espécie de males inerentes à realidade brasileira e, muitas vezes, [estes] são 'naturalizados', quando os atingidos são moradores de favelas e periferias." (Idem, 2005, p. 35). Relatam ainda, que o principal assunto discutido nas notícias girava em torno das "forças de segurança" (40,5\%), quais sejam as polícias e forças armadas (Idem, 2005, p. 19). Das notícias voltadas para o tema, $57,6 \%$ falam de operações policiais bem sucedidas, $16,5 \%$ tratam de crimes cometidos pela força policial, 9,8\% abordam as denúncias de crimes cometidos por policiais, e 3,3\% se referem a "utilização das forças armadas no combate à violência urbana". Dos 1108 artigos sobre as forças de segurança apenas onze falavam da corregedoria de polícia e um artigo falava sobre policiamento comunitário. (Idem, 2005, p. 21-22)

As autoras falam da desproporção entre o número de notícias sobre delitos policiais e o número de notícias sobre a ação disciplinar das corregedorias fato que demonstraria o início de uma tendência da imprensa de ocupar o lugar de mecanismo de controle externo das polícias, através de 
um “jornalismo de físcalização policial” (RAMOS\& PAIVA, 2005, p.20). Contudo, Ramos e Paiva deixaram de observar que devido à natureza individualizada das notícias, a imprensa, ao colocar o foco na atuação policial, ela acaba por privilegiar a polícia como o maior ou o único meio de controle da violência, fazendo cair no esquecimento outros caminhos muito mais razoáveis, como as políticas sociais que previnem e não simplesmente reprimem os atos violentos.

Outro resultado da pesquisa a ser mencionado é o número irrisório de notícias encontradas sobre empresas e medidas de segurança privada $(0,1 \%)$. Tal cobertura não faz jus à relevância do tópico para atualidade, haja vista a crescente busca por serviços e produtos de segurança privada em diversas áreas do mundo, inclusive no Brasil, como já foi exposto em capítulos anteriores. As autoras apontam para a rara divulgação da idade e sexo dos autores das condutas violentas (63, 7\% das notícias não divulgam). Quando a faixa etária foi mencionada, uma boa parte se concentrava na de jovens de doze a vinte cinco anos (17\% das notícias). Quando foi divulgado o sexo dos "transgressores", a maioria esmagadora era do sexo masculino (88\%).(RAMOS\& PAIVA, 2005, p. 25).

Considerando a totalidade da pesquisa, o homicídio foi o tipo de crime mais noticiado nos jornais $(44,8 \%)$. As autoras, no entanto, fazem uma ressalva especial no caso dos jornais cariocas, nos quais se observou um equilíbrio no noticiamento de delitos de homicídio e os de roubo e furto: “ $35,2 \%$ dos crimes noticiados são homicídios e $32,4 \%$ são roubos e furtos".(Idem, 2005, p. 27)

Outro dado relevante é a baixa cobertura de notícias sobre ONGs e questões de direitos humanos, apenas 2, 4\%. Em regra, estas poucas notícias tratavam de eventos específicos e não de aspectos mais profundos e conjunturais acerca dos temas.(RAMOS\& PAIVA, 2005, p. 33). Tais 
assuntos são de grande relevância social e estão constantemente nas pautas de discussão acadêmica, por isso, não poderiam ser deixadas de lado pelos jornais. Tal abstenção leva a uma alienação da grande parte dos leitores que não está diretamente engajado com as ONGs e o debate dos direitos humanos.

Um último ponto a ser destacado neste artigo é o insignificante número de artigos encontrados que ilustrem a função e as atribuições dos órgãos de justiça e do ministério público (4\% das notícias se dedicam a falar dessas entidades, e a maioria retrata casos pontuais), fato que pode fazer com que a maioria dos leitores a vejam tais instituições como meramente "investigadoras ou aplicadoras de sentenças". (RAMOS\& PAIVA, 2005, p. 31). O segundo artigo, nomeado Avaliando o sentimento de insegurança nos bairros da cidade do Rio de Janeiro e escrito por Ana Luísa Vieira de Azevedo et al. teve como “objetivo dimensionar, através de pesquisa quantitativa ${ }^{18}$, o sentimento de insegurança" dos moradores de cinco bairros da Cidade do Rio de Janeiro, em áreas com diferentes perfis sócio-econômicos: Lagoa e Botafogo (Zona Sul); Bonsucesso e Pavuna (Zona Norte); Campo Grande (Zona Oeste). ${ }^{19}$

Analisando alguns dados produzidos pela pesquisa, os autores apontam para a Lagoa como o bairro no qual os moradores mais se sentem inseguros, e eles atribuem isso os seguintes fatos: grande parte dos entrevistados ser de uma faixa etária acima dos 45 anos $(47,3 \%$ da amostra); boa quantidade dos entrevistados ou membros de sua família terem sido vítima de algum crime (41\%); 68\% por cento dos entrevistados conhecerem alguém que já tenha sido vítima de um delito (AZEVEDO et

18 "A amostragem por cotas levou em consideração a distribuição populacional de cada bairro segundo gênero e idade. Foram aplicados 400 questionários estruturados em cada bairro, somando 2.000 entrevistas ao todo." (AZEVEDO, et al., 2004, p. 2).

19 "A seleção dos cinco bairros componentes desta pesquisa foi feita levando-se em conta o IDH (Índice de Desenvolvimento Humano) de cada bairro, e segundo os fatores: renda, longevidade, escolaridade, a taxa anual de homicídios, e a população." (AZEVEDO et al, 2004, p.2.) 
al., 2004, p.29). De todos os que foram inquiridos no bairro da lagoa, $41 \%$ acreditavam que a criminalidade havia aumentado ("contra $32 \%$ em Bonsucesso, 23\% na Pavuna, 23\% em Campo Grande e 19\% em Botafogo"), quando na verdade, segundo o estudo, este bairro foi o que menos teve um crescimento de criminalidade dentre os pesquisados (Idem., 2004, p.10). Em todas as zonas, com exceção de Botafogo, muitos moradores admitiram ter mudado alguns de seus hábitos cotidianos, como sair de casa com objetos de valor em função da criminalidade.

Azevedo et al. revelou que grande parte dos questionados de todos os bairros julgou o policiamento em seus bairros menor do que o necessário, sendo os moradores da Zona Sul aqueles que mais expressam essa opinião $(62,9 \%)$ e Botafogo (47,8\%). Diante desta estatística, faz sentido que as duas medidas mais votadas para melhorar a segurança dos bairros tenham sido "aumentar o policiamento", "preparar melhor os policiais" (AZEVEDO et al., 2004, p.16)

Para um número considerável dos entrevistados de todos os bairros as notícias divulgadas pela mídia retratam de maneira eficaz os fatos ocorridos, e mais da metade de todos os entrevistados (52\%) declarou que é através dos meios de comunicação (rádio, jornais e televisão) que ficam sabendo sobre os crimes praticados. Também foi consenso entra todas as áreas que o foco dos jornais é a ocorrência de delitos no Rio de janeiro, e eles atribuem esse fato ao crime organizado carioca. (AZEVEDO et al., 2004, p.22).

Os pesquisadores compararam o medo das pessoas de um bairro com relação a determinados crimes, o que eles chamam de "insegurança subjetiva", com os dados fornecidos pelo ISP sobre o registro oficial de ocorrências desses crimes no mesmo bairro, a "insegurança objetiva" (Idem., 2004, p.23). Ao fazer isto eles observaram que a sensação de medo 
crescente não tem relação com a ocorrência efetiva de delitos. Exemplo disso é o caso do crime de roubo de residência, o qual na Pavuna, "nos meses de abril e maio, enquanto cresce o número de casos de roubo a residência, decresce o medo de ser vítima deste crime" e "na Lagoa, apesar do número de roubo a residência permanecer estável nos meses de abril, maio e junho, na percepção dos entrevistados o medo aumenta".

As principais conclusões que podem ser tiradas desses artigos é que independente da insegurança objetiva existente nos bairros estudados, o grau de insegurança subjetiva tende a ser crescente. Se aliarmos essa desarticulação a confiança predominante que se tem na mídia e na precisão desta ao retratar fatos criminosos, podemos dizer que o papel destes é talvez mais relevante para gerar insegurança do que os atos criminosos em si. A este respeito Azevedo et al. citam Sebastian Roché, falando que "a insegurança se alimenta muito mais de impressões difusas e distantes da realidade cotidiana do ator social do que de fatos reais." (Idem., 2004, p.11).

Também podemos observar que a repetida publicação de artigos sem contextualização e dados estatísticos e conteúdo crítico, observada na primeira pesquisa, pode fazer com que os leitores cultivem uma sensação de insegurança abstrata, desvinculada a dados e conclusões racionais e vinculada a descrição ligeira de atos brutais. A apresentação de muitos acontecimentos violentos no formato de notas soltas nos jornais, valoriza os fatos delituosos isolados, e acaba naturalizando estes como parte integrante da vida cotidiana em uma determinada região.

Através destes dois artigos pôde-se ter um pequeno exemplo de como se constrói um imaginário do medo através da produção de um discurso jornalístico concretizado em elementos como: a escolha de divulgar ou não informações estatísticas; a escolha de focos, tipos de 
enquadramento diversos, formatos de diagramação (notas ou editoriais ou artigos em cadernos locais); no nível de detalhamento sobre o perfil dos personagens envolvidos no fato noticiado. E também de como se configura o sentimento de insegurança de moradores de diversas situações sociais que tomam a mídia como fonte confiável de informação e parâmetro de avaliação da realidade que os cerca. Parece que as representações do real fornecidas pelos meios de comunicação teve maior poder de convencimento que uma realidade ligada à insegurança objetiva.

Não se pode olvidar que diversos artigos de jornais tiveram um papel importante na aceleração e criação de projetos de lei que endurecem as penas e o regime penal brasileiro. Um exemplo digno de nota é o caso da morte do menino João Hélio, ocorrida no dia 7 de fevereiro de 2007.

A intensa cobertura midiática deste acontecimento trouxe para as mesas de discussão a questão da maioridade penal, das condutas infracionais cometidas por menores, e da suposta impunidade destes jovens devido às regras vigentes. $\mathrm{O}$ alarde feito pela mídia a cerca da trágica morte do menino João Hélio, tragédia esta que atinge tanto a família do menino como também as vidas dos rapazes que acabaram por ocasioná-la, levou a manifestações públicas de cidadãos indignados, de políticos revoltados, de artistas chocados, e até de jornalistas sensibilizados, formando um grande lobby a favor das políticas de diminuição da maioridade penal, que levou até a elaboração e votação de um projeto de lei a cerca do assunto.

Os meninos foram retratados como demônios, delinqüentes maus por natureza, que fizeram o ato atroz de maneira propositada e fria. O jornal o globo publicou por mais de uma semana artigos que falavam sobre a comoção pública acerca do acontecido. Um deles foi o pronunciamento do governador Sérgio Cabral, feito apenas cinco dias depois do ocorrido, com clara visão eficientista, intitulado "Resposta à barbárie", publicado no primeiro caderno do dia 13/02 de 2007:

No dia 8 de fevereiro o Brasil inteiro chorou (...) Nem em um filme de fícç̧ão de terror qualquer diretor se atreveria a encenar tamanha crueldade com uma criança 
(...) o governo do Estado do Rio está em guerra conta a criminalidade, seja de que tipo for, contra quem quer que seja o criminoso. Para vencer essa guerra, precisamos agir em duas frentes: dotar a polícia de sofisticados equipamentos, principalmente na área da inteligência (...), e promover uma maior presença da polícia ostensiva nas ruas. ${ }^{20}$ (FILHO, 2007, p. 1)

Pode ser vista no discurso do governador uma ótica coerente com os princípios do Eficientismo Penal, tais como o uso do termo "guerra" e a idéia de que o policiamento bem equipado e mais ostensivo consistiria na política ideal de combate ao crime.

Mais adiante, sobre o anteprojeto de lei apresentado pelo governo do Estado do Rio de diminuição da maioridade penal, o governador fala:

A proposta é a de se criar, assim como existe a emancipação do menor de 18 anos para a práticas de atos na vida civil, a possibilidade de emancipação jurídica penal do adolescente infrator. (FILHO, 2007, p.1)

Uma outra manchete, publicada no mesmo jornal e no mesmo dia demonstra como a grande repercussão da morte do menino levou a imediata reação do poder público, com o reexame de diversas propostas e discussão de projetos que se relacionem a ela:

Senado reabre debate sobre maioridade penal: seis propostas de emenda constitucional que tratam do assunto serão desengavetadas (VASCONCELO, 2007, p.1)

Também é interessante notar a faceta espetaculizadora da tragicidade do evento, contida nas inúmeras matérias e declarações de cidadãos emocionados e revoltados, assim como nos artigos descrevendo as manifestações populares realizadas por pessoas chocadas com o ocorrido. Exemplos de manchetes desse gênero são:

Uma Corrente de solidariedade e revolta, através de cartas, da internet e de ações, milhares de pessoas se manifestam (SCHMIDT, 2007, p1.);

O adeus a João: durante missa, que reuniu 600 pessoas, padre compara sofrimento do menino ao de Cristo (ROCHA, 2007, p.1)

\footnotetext{
${ }^{20}$ Grifo meu.
} 
O exemplo da cobertura da morte de João Hélio mostra que a construção de um imaginário de medo e insegurança em torno da violência praticada por um setor determinado e marginalizado da sociedade leva a um deslocamento de foco, conveniente às classes dominantes, pois, afinal, a grande questão a ser discutida não seria diminuição da maioridade penal, ou o maior rigor das penas para os praticantes de delitos violentos, mas sim a discussão dos agentes causadores da violência, da desigualdade, da frustração e exclusão social de um contingente tão grande da população. Notícias como estas estimulam o medo e a busca por proteção social e manutenção da ordem. Fazem com que seja possível discutir de maneira natural o aprisionamento de jovens menores de 18 anos, permitem que discursos de apologia a tortura floresçam, e assim por diante. 


\section{Conclusão}

Através das análises efetuadas nos capítulos do presente trabalho, pôde-se ver que nas últimas décadas, a sociedade contemporânea sofreu diversas mazelas oriundas do processo de consolidação do regime capitalista de acumulação flexível, em voga na atualidade. Uma das mais preocupantes é a exclusão de um expressivo contingente populacional do mercado de trabalho e de consumo. Esta se deu devido às políticas de flexibilização das relações humanas, principalmente as de trabalho, que acarretou um desemprego estrutural e uma decorrente insegurança, ligada à falta de estabilidade financeira e benefícios trabalhistas, a qual coincidiu com a desestruturação do Estado Social e suas políticas de bem estar.

Os setores improdutivos da sociedade passaram a ser vistos como uma possível ameaça a ordem, e, para contê-los, foram desenvolvidos diversos mecanismos de controle social. A maior parte destes tem um cunho emergencial e eficientista, e são estruturados com o fim de manter a "lei e a ordem" estabelecidas pelos grupos dominantes. Tais políticas penais têm como características: a repressão intensa das populações marginalizadas, a crescente militarização das forças policiais, um pesado investimento no emparelhamento policial e uma belicização das terminologias usadas para tratar dos assuntos criminais.

Dentro dessa lógica repressiva, os excluídos passaram a ser designados pelos discursos oficiais e da mídia como um inimigo interior do Estado contemporâneo, e se tornaram a concretização dos "medos reprimidos e circundantes" que "permeiam a vida e a 'normalidade"' dos bons cidadãos (BAUMAN, 1998, p. 52-53). Por isso, passam a ser vigiados, punidos e extirpados do convívio social.

Os sistemas de controle social passaram ser criminalizadores da pobreza, pois direcionam suas ações repressivas aos delitos cometidos em regra pelos "excluídos e despossuídos", e criam uma atmosfera de medo em 
torno de todo o setor marginalizado da sociedade, estigmatizando este, portanto, como "classe perigosa" e "criminosa em potencial".

O exemplo da política de "Tolerância Zero" ilustrou bem essa tendência, pois além de ter um suporte teórico de cunho biológico que alegava a inferioridade cognitiva dos grupos marginalizados, tem também como regra orientadora a repressão de toda e qualquer conduta desordeira, por menor que seja, com o suposto propósito de prevenir a prática de delitos mais graves. A construção da mídia em volta do modelo através da repetida veiculação em noticiários impressos e televisionados retratando a política de "Tolerância Zero" como a "panacéia" (DORNELLES, 2003, p. 64) para toda a desordem e insegurança teve um relevante papel na adoção desta lógica por diversas nações européias e latino-americanas.

$\mathrm{Na}$ atualidade, os Estados reservam grande parte de seu orçamento e do seu tempo discutindo e investindo em assuntos de segurança. Com o fim das políticas de bem estar o Estado tem como instrumentos legitimadores de poder a luta pela ordem e o combate ao medo e insegurança. Os governantes fazem do discurso de guerra ao inimigo da ordem um de seus principais focos de gestão. A escolha de inimigos internos como o terrorista, no caso americano, e o traficante no caso carioca, aliada ao sentimento difuso de insegurança e da necessidade premente pela ordem, acaba por dar aos Estados maior liberdade de atuação. Permitindo, assim, que suas instituições, como a polícia e órgãos legisladores, privem cada vez mais os cidadãos de seus direitos e garantias. A noção de direitos humanos é, portanto, relativizada através de leis, como a lei antiterrorista no caso americano, e de atuações repressivas e violentas, como as incursões da polícia carioca nas favelas da cidade do Rio.

Assim como o Estado toma proveito do medo e da construção de um imaginário de insegurança, também o fazem as corporações, através de campanhas publicitárias que estimulam a compra de produtos e serviços 
para proteção pessoal, de remédios para lidar com as ansiedades de maneira eficiente e rápida, de livros de auto-ajuda para orientar de forma genérica as pessoas perturbadas pelas frustrações e insucessos decorrentes do próprio sistema capitalista.

Como foi visto ao longo do trabalho, a culpa pelo insucesso e exclusão do meio produtivo não é atribuída ao sistema, mas aos próprios marginalizados. Estes, vistos como uma ameaça são alvos de políticas neutralizadoras, as quais naturalizam a situação de desigualdade social (discurso biológico de inferioridade intelectual dos setores despossuídos é um exemplo desses discursos naturalizantes, assim como a idéia de consenso social que foi discutida no primeiro capítulo).

O objetivo de neutralizar as desconformidades e os desviantes se estende até aos métodos de tratamento psicológico, sendo os mais recomendados aqueles que se baseiam na utilização de remédios, os quais tendem a prejudicar o raciocínio, a capacidade de memória, deixando os pacientes dóceis e tranqüilos. A psicanálise é criticada e pouco recomendada por implicar no resgate da individualidade, da história e do desejo particular de cada paciente.

O estudo do pânico da morte, ligado à inevitabilidade da morte e às maneiras encontradas de lidar com a idéia inconcebível do fim da existência, levou ao conhecimento dos mecanismos contemporâneos de banalização (o ensaio constante do fim através da morte de entes queridos e do fim de relacionamentos amoroso e sociais- o que Bauman chama de morte metafórica e que, na contemporaneidade, se tornam cada vez mais freqüentes) e desconstrução (através de uma visão casuística da morte, consistente na acepção desta como um evento de causas específicas, tal qual uma enfermidade evitável ou um acidente) da morte. 
O processo descrito é semelhante à forma que os governos e cidadãos lidam com o medo da exclusão, que seria uma morte social. Isto porque a mídia, as corporações, e os Estados utilizam-se freqüentemente de mecanismos que desacoplam o sentimento de insegurança de suas causas essenciais (como a desigualdade social, a natureza excludente e massacrante do sistema econômico em vigor), engendrando causas fabricadas, perigos artificiais.

Alguns exemplos destes mecanismos são: a criação dos inimigos internos selecionados pela sua visibilidade e atuação delituosa nos lugares públicos; a espetaculização da violência na mídia por meio de imagens apavorantes e de artigos que descrevem fatos pontuais e com pouca contextualização.

Pôde se chegar à idéia de que a população é tomada atualmente por um sentimento de insegurança que é constantemente renovado e de causa indefinida e flutuante (os perigos artificiais estão em constante renovação juntamente com os medos). As inseguranças são reforçadas até mesmo pelos mecanismos que se propõem a proteger os cidadãos, tais quais os muros, os serviços de segurança privada, as câmeras de vigilância, que ao mesmo tempo em que causam uma sensação de proteção, constituem lembretes permanentes da conjuntura violenta e desordeira que os fez necessários.

Essa atmosfera de medo foi bem capturada pela pesquisa realizada pelo ISP que entrevistou diversos moradores de áreas de realidades sócioeconômicas distintas. $\mathrm{O}$ que se aferiu foi que os moradores dos bairros mais ricos (como lagoa e botafogo) eram o que mais se sentiam inseguros, e tinham a sensação de que a criminalidade estava crescendo, quando na verdade esta estava estável ou diminuindo. Estes cidadãos declararam a mídia como sua fonte primária de informação e consideravam-na segura e confiável. Ao comparar este estudo com a pesquisa feita pelo CESeC, que 
analisou a forma de abordagem de fatos violentos nos veículos de comunicação impressos, foi visto que os jornais lidos por essa camada da população, que se configurou mais atemorizada, fornece aos seus leitores notícias descontextualizadas, descritivas de fatos violentos pontuais que mal identificam propriamente os agentes, as causas sociais e políticas destes delitos. Este tipo de artigo gera uma reação emocional nos leitores, com suas narrativas sangrentas e sem muito conteúdo critico.

Os leitores, ao lerem tais notícias, têm como reação não a reflexão ou a percepção racional da conjuntura social, mas sim o choque e o medo. Isto porque eles pouco têm a seu dispor para refletir sobre a conjuntura na qual estes fatos estão inseridos, por não poder perceber de maneira mais ampla as causas reais desses episódios violentos e o significado destes em no contexto social. Não podem, portanto levar em conta os jogos de poder que existem na realidade contemporânea e as falhas no regime econômico vigente, os quais causam tantas mazelas para a sociedade.

O caso do menino João Hélio forneceu uma ilustração complementar as percepções aferidas das duas pesquisas de campo analisadas, exemplificando a capacidade da mídia de despertar reações emocionais a fatos violentos noticiados. Foi vista também o uso do impacto catártico de tais notícias para manifestar e exercer seu poder, seja fazendo pronunciamentos oficiais, seja propondo projetos de lei, seja rediscutindo antigas questões no congresso que antes estavam adormecidas. Não se pode esquecer-se de mencionar a importância da veiculação de acontecimentos como estes, e das conseqüentes manifestações das classes dominantes, para reiterar a validade do modelo de controle penal seletivo, reforçar a demonização dos setores pobres, fortalecer a figura do inimigo interno e canalizar os medos sociais para classe de "criminosos em potencial". 
A presente monografia foi importante para aumentar e clarificar o conhecimento da pesquisadora sobre os temas abordados. Ciente das limitações inerentes ao trabalho monográfico, a autora do presente trabalho reconhece a existência de muitos outros pontos a serem abordados. Alguns possíveis caminhos para aprofundar a pesquisa seriam: a análise da visão de inimigo interior proposta por Hannah Arendt; um estudo mais aprofundado, sob uma perspectiva psicológica, do medo e de seus agentes causadores; uma compreensão mais abrangente do processo de formação de imaginário social, tomando como ponto de partida o estudo da obra de Cornelius Castoriadis; e, por fim, alcançar maior familiaridade com a obra de Karl Marx e seu método materialista histórico dialético de análise. 


\section{Referências Bibliográficas}

AZEVEDO, Ana Luiza Viera de, et al. Avaliando o sentimento de insegurança nos bairros d cidade do Rio de Janeiro. NUPESP, ISP. 2004. Disponível em: $<$ http://urutau.proderj.rj.gov.br/isp_imagens/Uploads/Artigo2004001.pdf $>$. Acesso em: 14 Fev. 2008.

BATISTA, Vera Malaguti. O Medo Na Cidade Do Rio De Janeiro: Dois tempos de uma história. 272p. Rio de Janeiro: Revan: 2003.

BAUMAN, Zygmunt. O Mal-estar Na Pós-modernidade. Rio de Janeiro: Jorge Zahar Ed., 1998. 272p.

. Em Busca da Política. Rio de Janeiro: Jorge Zahar Ed., 2000. 213p.

. Medo líquido. Rio de Janeiro: Jorge Zahar Ed., 2008. 239 p.

CORRÊA, Felipe. Imaginários do Medo: Imprensa e violência urbana. Rio de Janeiro. Rio de Janeiro, 2008. 188p. Dissertação de Mestrado Departamento de Comunicação Social, PUC-Rio.

DORNELLES, João Ricardo W. Conflito e Segurança - entre Pombos e Falcões. Rio de Janeiro: Lúmen Iuris, 2003. 222p.

HARVEY, David. The Condition of Potmodernity. 1 ed. Malden: Blackwell Publishing, 1990. 378p. . A Condição Pós-moderna - uma investigação sobre as origens da mudança cultural. São Paulo: Edições Loyola, 1992. 349p. 
FILHO, Sérgio Cabral. Resposta à Barbárie. O Globo (versão digital), Rio de Janeiro, Primeiro caderno. P. 1-2. 13 de fevereiro de 2007. Disponível em: $<\underline{\text { http://www.experimenteoglobo.com.br/ filp/tools/flipprint/printMateria. }}$ php?idmateria=87..> Acesso em: 13 de fev, de 2007.

RAMOS, Silvia e PAIVA, Anabela. Mídia e Violência- Como os jornais retratam a violência e a segurança pública no Brasil. Rio de Janeiro: CESeC, maio de 2005. Disponível em: <http://www.ucamcesec.com.br/pb_txt_dwn.php>. Acesso em 3 de Mar. de 2008.

ROCHA, Carla. O adeus a João. $O$ Globo (versão digital), Rio de Janeiro, Primeiro caderno. P. 1-2. 14 de fevereiro de 2007. Disponível em: $<$ http://www.experimenteoglobo.com.br/ filp/tools/flipprint/printMateria. php?idmateria=26>. Acesso em: 14 de fev. de 2007.

SAPIA, Jorge Edgardo. Algumas considerações sobre a violência e o terror como forma de dominação: o caso argentino. Dissertar. N. 8 e 9. p.46 a 50. Jan/Dez 2005.

SCHMIDT, Selma. Uma corrente de solidariedade e revolta. O Globo (versão digital), Rio de Janeiro, Primeiro caderno. P. 1-2. 13 de fevereiro de 2007. Disponível em: < $\underline{\text { http://www.experimenteoglobo.com.br/ }}$ filp/tools/flipprint/printMateria. php?idmateria=8a..> Acesso em: $13 \mathrm{de}$ fevereiro de 2007.

SOBRINHO, Sergio Graziano. A cultura do medo e as transgressões contemporâneas. Direito, Estado e Sociedade. V.9. N.27. P. 215 a 226. Jul/dez 2005.

VALLADARES, Lícia. Cem Anos Pensando a Pobreza (Urbana) No Brasil. In:Boschi, Renato (org.). Corporativismo e desigualdade: a construção do espaço público no Brasil.Rio de janeiro: Rio Fundo Ed.,: IUPERJ, 1991. 
VASCONCELO, Adriana. Senado debate sobre maioridade penal. O Globo (versão digital), Rio de Janeiro, Primeiro caderno. P. 1-2. 13 de fevereiro de 2007. Disponível em: http://www.experimenteoglobo.com.br/ filp/tools/flipprint/printMateria. php?idmateria $=$ ac... $>$ Acesso em: $13 \mathrm{de} \mathrm{fev}$ de 2007.

VICENTINO, Claudio. História Geral. São Paulo: Scipione, 1997. 495p. 
